\title{
Novel human recombinant antibodies against Mycobacterium tuberculosis antigen 85B
}

\author{
Manon Fuchs', Susanne Kämpfer ${ }^{2}$, Saskia Helmsing ${ }^{1}$, Ralf Spallek², Wulf Oehlmann², Wiebke Prilop², \\ Ronald Frank ${ }^{3,4}$, Stefan Dübel ${ }^{1}$, Mahavir Singh ${ }^{2}$ and Michael Hust ${ }^{1 *}$
}

\begin{abstract}
Background: Tuberculosis is the leading cause of death due to bacterial infections worldwide, mainly caused by Mycobacterium tuberculosis. The antigen 85 complex comprises a set of major secreted proteins of $M$. tuberculosis, which are potential biomarkers for diagnostic.

Results: In this work, the first human single chain fragment variable (scFv) antibodies specific for the tuberculosis biomarker 85 B were selected by phage display from naïve antibody gene libraries (HAL7/8). Produced as ScFv-Fc in mammalian cells, these antibodies were further characterized and analysed for specificity and applicability in different tuberculosis antigen detection assays. Sandwich detection of recombinant 85 B was successful in enzyme linked immunosorbent assay (ELISA), lateral flow immunoassay and immunoblot. Whereas detection of M. tuberculosis cell extracts and culture filtrates was only possible in direct ELISA and immunoblot assays. It was found that the conformation of $85 \mathrm{~B}$, depending on sample treatment, influenced antigen detection.

Conclusions: Recombinant antibodies, selected by phage display, may be applicable for 85 B detection in various assays. These antibodies are candidates for the development of future point of care tuberculosis diagnostic kits. Using $85 \mathrm{~B}$ as a biomarker, the antigen conformation influenced by sample treatment is important.
\end{abstract}

\section{Background}

Approximately 8.7 million people worldwide fell ill with tuberculosis (TB) in 2011 and 1.4 million deaths were reported [1]. Worldwide TB ranks as the second major cause of death from an infectious disease. One third of the world population is estimated to be infected with $M$. tuberculosis (Mtb), yet they remain asymptomatic. This is defined as latent TB infection (LTBI) [2]. Only $66 \%$ of the TB-cases worldwide are correctly diagnosed [1]. The gold standard in TB diagnosis remains the preparation of liquid cultures in selective media from sputum or tissue/ body fluid specimens [3]. This is followed by further Mtb specific tests or drug susceptibility testing (i.e. nucleic acid amplification tests such as the Gene Xpert MTB/RIF [4]).

Diagnosis of TB in most low- and middle-income countries continues to rely on sputum smear microscopy for acid-fast bacilli (Ziel-Neelsen stain) [1]. This technique detects only $40-60 \%$ of pulmonary TB cases and is not able

\footnotetext{
* Correspondence: m.hust@tu-bs.de

${ }^{1}$ Technische Universität Braunschweig, Institut für Biochemie und Biotechnologie, Spielmannstr.7, 38106 Braunschweig, Germany Full list of author information is available at the end of the article
}

to differentiate between Mtb and other ubiquitous mycobacteria $[5,6]$. This is less sensitive in children, HIV coinfected patients and in patients with extrapulmonary $\mathrm{TB}$ $[7,8]$. The diagnosis of $\mathrm{TB}$ in developing countries is limited by equipment and infrastructure [1]. Therefore, in these countries, a simple diagnostic tool without the need for sophisticated instruments is needed. Accuracy, simplicity, affordability and technical robustness are important factors for a point of care (POC) TB-test. The main advantage of this is a rapid diagnosis, which allows initiation of treatment while the patient is still accessible [9]. Several anti-tuberculosis antibody detection systems are available. However the WHO recommended against the use of these assays because of their lack of sensitivity and specificity [10]. Direct detection of Mtb antigens in human specimens would allow specific diagnosis of active TB to be made, independent of the host's immune response. Furthermore, the use of specific antibodies to Mtb antigens in a lateral flow immuno assay (LFIA) would potentially provide a rapid POC test in a cost effective, easy-to-use format. Potential target antigens for POC TB-detection in human samples should be selected by the following 
criteria: substantial expression by bacteria in vivo, presence in the extracellular environment or on the mycobacterial cell wall, and resistance to degradation by host enzymes [11]. The 85 complex is a major secretion product of Mtb $[12,13]$ which comprises three variant 85 proteins $(\mathrm{A}, \mathrm{B}$ and $\mathrm{C})$ that are encoded by three different genes (fbpA, fbpB and fbpC2, [14]). Antigens $85 \mathrm{~A}, 85 \mathrm{~B}$ and $85 \mathrm{C}$ possess mycoyltransferase activity and are involved in the formation of trehalose monomycolate (TMM) and trehalose dimycolate (TDM), which are components of the mycobacterial cell wall $[15,16]$. Besides the 85 complex there is another 85 protein, known as $85 \mathrm{D}$ or FbpC1. $85 \mathrm{D}$ shows structural similarity to the 85 complex proteins, yet does not possess mycoyltransferase activity [15] and its function remains unknown. Disruption of $\mathrm{fbpA}$ results in the inability of Mtb to replicate within macrophages, indicating a key role in virulence [17]. Furthermore, it was shown that 85 complex proteins interact with gelatine-binding sites of human fibronectin, enhancing complement-mediated phagocytosis by macrophages [18-20]. Antibodies specific for only one of the 85 proteins would allow for further investigation of their individual roles in the pathogenesis of TB. However only antibodies cross reacting with all other 85 complex proteins have been reported so far [21-23].

The presence of the 85 complex was demonstrated in human serum [24], urine [20], cerebrospinal fluid [25] and sputum [26] of TB infected individuals. This makes it a prominent marker for TB. Although other mycobacteria express similar 85 complex proteins, these antigens could be used as TB markers in combination with other antigens to enhance specificity.

For the future development of diagnostic assays, recombinant antibodies generated by phage display are an alternative to polyclonal and monoclonal antibodies [27-32]. Naïve antibody libraries allow generation of antibodies to epitopes which are not recognized by any immune system. In addition, recombinant human antibodies could be used in therapeutic applications. In this work, single chain Fv $(\mathrm{scFv})$ were isolated from a human naïve antibody gene library using phage display [33] and produced as scFv-Fc (yumab) [34]. These antibodies were further characterized and analysed for their suitability in an antigen detection assay targeting Mtb $85 \mathrm{~B}$.

\section{Results}

\section{Selection of human antibodies against 85 B}

For antibody selection, panning was performed on immobilized $85 \mathrm{~B}$ followed by a screening ELISA using soluble scFv (see Additional file 1: Figure S1). Finally, five unique scFv were confirmed by DNA sequencing. The corresponding human germline sequences according to VBASE2 [35] are displayed in Table 1. All $\alpha-85$ B antibodies contain a variable gene segment of the heavy chain (HV) of subfamily $\mathrm{V}_{\mathrm{H}}$ 3. Four binders have a lambda light chain $\left(\mathrm{V}_{\mathrm{L}} \lambda\right)$ and one has a kappa light chain $\left(\mathrm{V}_{\mathrm{L}} \mathrm{K}\right)$. All $\mathrm{V}_{\mathrm{L}} \lambda$ clones have a joining segment of the heavy chain $(\mathrm{HJ})$ of subfamily J4, a joining segment of the light chain (LJ) of subfamily J3, and a variable gene segment of the heavy chain (HV) of subfamily $\mathrm{V}_{\mathrm{H}} 3$ gene 30 .

\section{Cloning and production of scFv-Fc (Yumabs)}

The scFv were subcloned into pCSE2.5-hIgG1-Fc-XP [34], produced in $50 \mathrm{~mL}$ scale and purified from the culture supernatant via Protein A. The purified scFv-Fc (Yumabs) were analysed by SDS-PAGE, silver staining, $\alpha$-human $\operatorname{IgG}(\mathrm{Fc})$ immunoblot and reducing gel analysis via Tape Station. No degradation was detected (data not shown). The purity of the obtained antibody preparations was determined to $93.4-96.9 \%$.

\section{Validation of antigen binding}

The antigen binding of the Yumabs was analysed by titration ELISA (Figure 1A). The antigen binding was confirmed for all Yumabs. Antigen detection limits of the $\alpha-85$ B scFv-Fc were determined by antigen titration ELISA (Figure 1B). About $5 \mathrm{ng} / \mathrm{mL}$ were detected by MFU50C10, $10 \mathrm{ng} / \mathrm{mL}$ by MFU50-A10 and MFU50-E2, and $30 \mathrm{ng} / \mathrm{mL}$ by MFU50-D4 and MFU50-D7.

\section{Epitope mapping}

To determine whether the antibodies bind to linear or conformational epitopes, the $\alpha-85 \mathrm{~B}$ scFv-Fc were analysed by immunoblot (data not shown). All antibodies

Table 1 Comparison of heavy and light chain gene segments of a-85 B antibodies

\begin{tabular}{|c|c|c|c|c|c|}
\hline \multirow[b]{2}{*}{ Clone } & \multicolumn{3}{|c|}{ Heavy chain } & \multicolumn{2}{|c|}{ Light chain } \\
\hline & $\mathrm{HV}$ & D & $\mathrm{HJ}$ & LV & LJ \\
\hline MFU50-A10 & IGHV3-30*04 & IGHD6-19*01 & IGHJ4*02 & IGLV8-61*01 & IGLJ3*02 \\
\hline MFU50-C10 & IGHV3 & IGHD2-15*01 & IGHJ6*02 & IGKV1-12*01 & IGKJ2*01 \\
\hline MFU50-D4 & IGHV3-30*18 & IGHD3-3*02 & $\mid \mathrm{GHJ} 4^{*} 02$ & IGLV2-14*01 & IGLJ3*01 \\
\hline MFU50-D7 & IGHV3-30*04 & IGHD4-17*01 & IGHJ4*02 & IGLV3-21*02 & IGLJ3*02 \\
\hline MFU50-E2 & IGHV3-30*03 & IGHD6-13*01 & $\mid \mathrm{GHJ} 44^{*} 02$ & IGLV7-43*01 & IGLJ3*02 \\
\hline
\end{tabular}

Abbreviations: $H V$ variable $(\mathrm{V})$ gene segment of the heavy chain, $D$ diversity gene segment, $H J$ joining $(J)$ gene segment of the heavy chain, $L V$ variable gene segment of the light chain, $L$ joining gene segment of the light chain. 

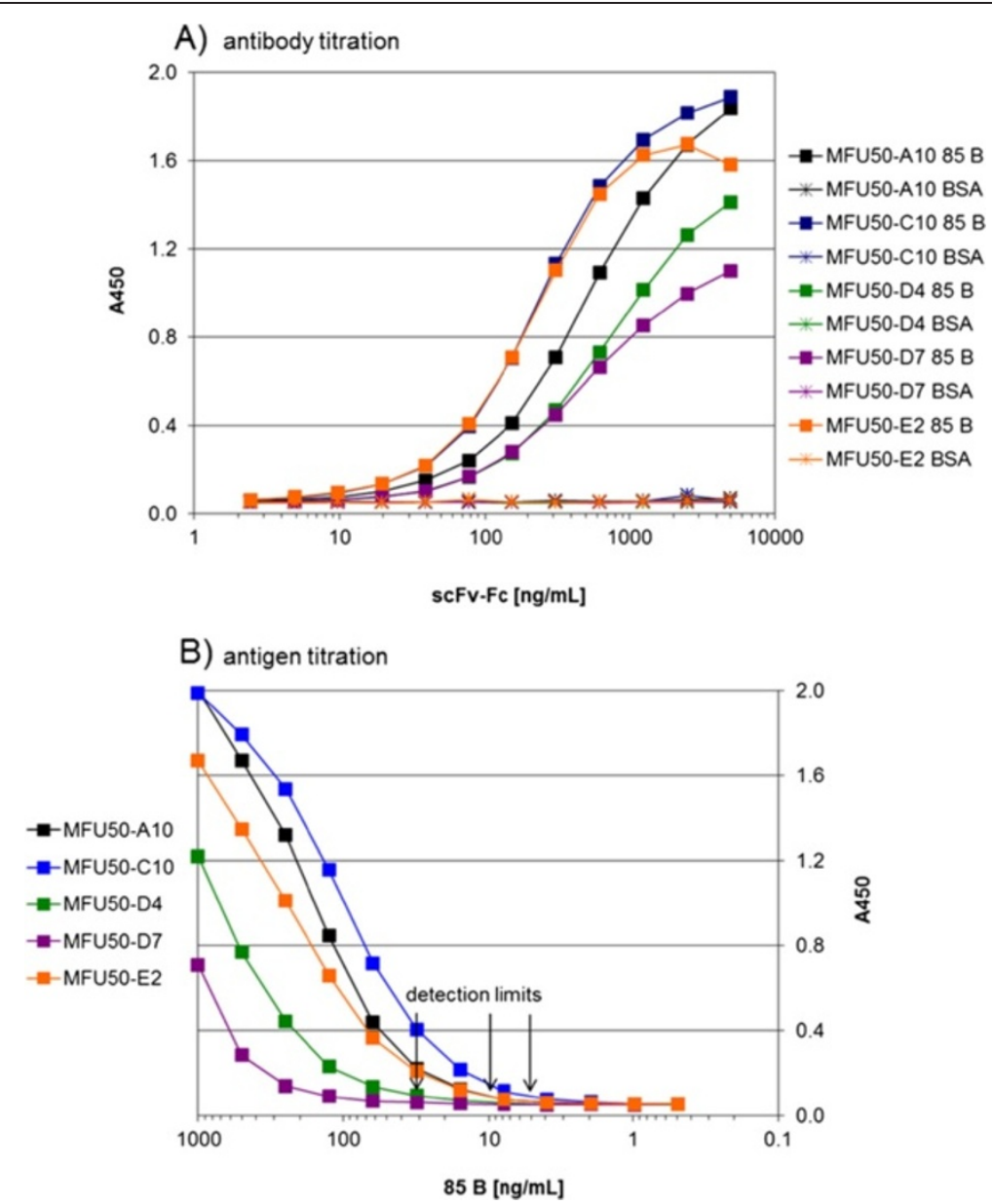

Figure 1 Analysis of antigen binding. A) Antibody titration and B) antigen titration in ELISA with a-85 B scFv-FC. A) Dilution series of scFv-FC were used for detection of directly coated antigen ( 85 B) or BSA (negative control). Detection of bound scFv-Fc with goat a-human IgG(Fc)-HRP and development with TMB. B) Different dilutions of antigen ( 85 B) were directly coated to the wells. Antigen detection with a scFv-Fc concentration of half maximal saturation. Detection of bound scFv-Fc with goat a-human lgG(Fc)-HRP, development with TMB. Negative control BSA A450 =0.05.

recognized linear epitopes (data not shown). Epitope mapping of the $\alpha-85 \mathrm{~B}$ scFv-Fc was carried out on PepSpot membranes (Figure 2A). Through the overlap of the peptide sequences the epitopes were determined (Figure $2 \mathrm{~B}$ ). The crystal structure of antigen $85 \mathrm{~B}$ was determined by Anderson et al. [36] and the epitopes were visualized on the 3D structure of the antigen (Figure 2C). The distance between epitope regions "AFSRPGPLV(EYL)" and "SPAVYL" was computed to $\sim 2.5 \mathrm{~nm}$, between "SPAVYL" and "SSDPAWERN(DPT)" to $\sim 4 \mathrm{~nm}$ and between "SSDPAWERN(DPT)" and "AFSRPGPLV(EYL)" to $\sim 5 \mathrm{~nm}$. Considering the width of an antibody ( 4 nm, [37]), sandwich detection was likely targeting epitopes on different sites of the antigen.

\section{Cross reactions}

Sequence comparison of the epitopes of the $\alpha-85$ B antibodies with corresponding sequences of the other 85 complex antigens provided information about possible cross reactions (Table 2). The complete epitope "AFSRPGPLV (EYL)" is present in antigen $85 \mathrm{~A}$ and $85 \mathrm{C}$, but not in 85 D. Homologous regions of the epitopes "SPAVYL" and "SSDPAWERN(DPT)" can be found in $85 \mathrm{~A}, \mathrm{C}$, and D. Experimental study of 85 complex cross reactivity was carried out by indirect ELISA (Figure 3). MFU50-A10 reacted with $85 \mathrm{~A}$ and $85 \mathrm{D}$. MFU50-D4 displayed a weak cross reactivity with $85 \mathrm{~A}$ as predicted. MFU50-E2 bound antigen 85 B weakly and showed no cross reactions. MFU50D7 reacted weakly with $85 \mathrm{~B}$. No reaction with the other 85 complex antigens was detected. MFU50-C10 was also not cross reactive. A summary of the expected cross reactions in comparison to determined cross reactions is outlined in Table 2.

Detection of $85 \mathrm{~B}$ in Mtb cell extracts and culture filtrates The antibody binding to Mtb/BCG cell extracts and culture filtrates was analysed by indirect ELISA (Figure 4). In this assay only MFU50-A10 reacted with Mtb culture 


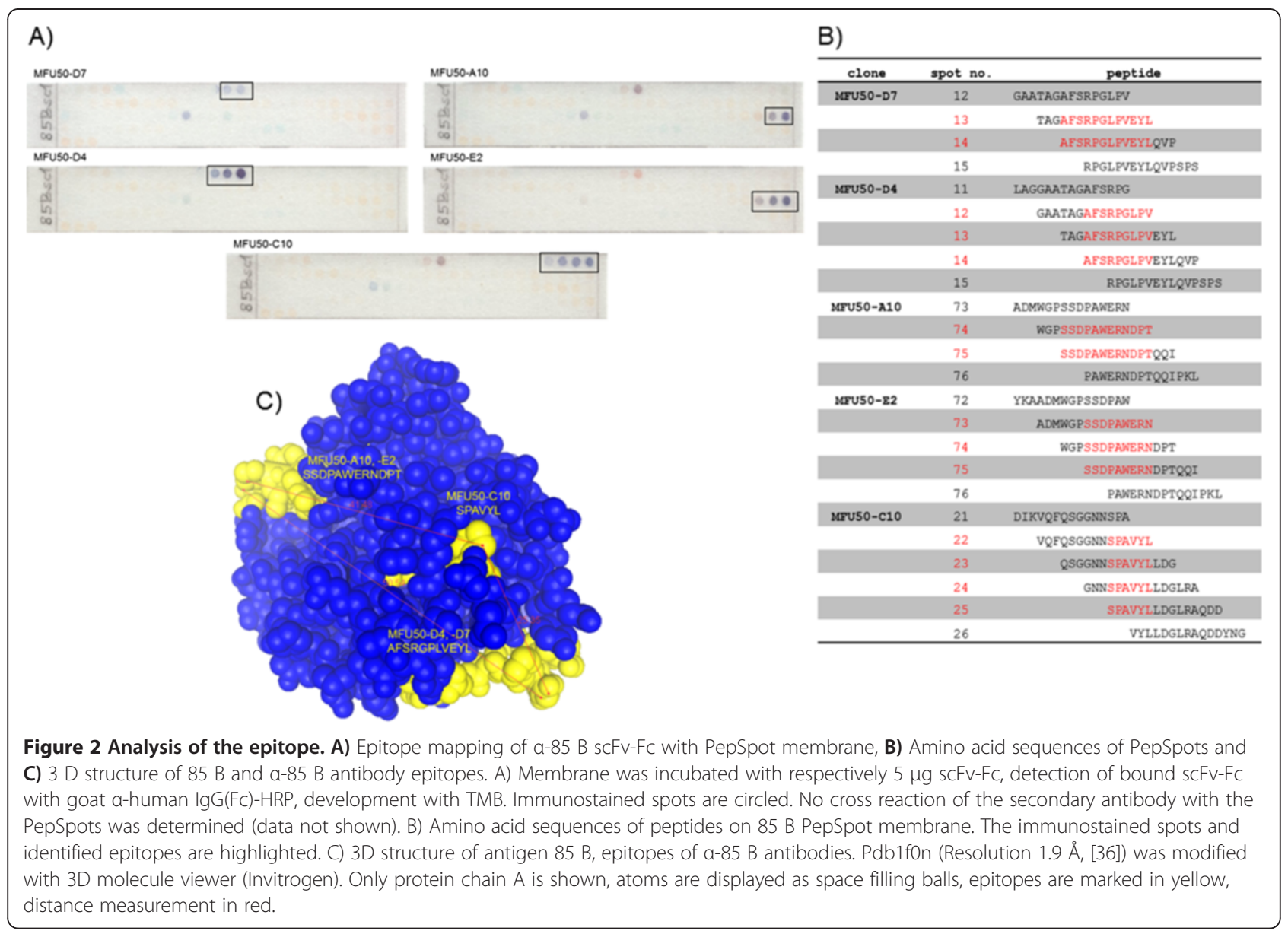

Table 2 Cross reactions of $a-85$ B antibodies with other 85 complex antigens

\begin{tabular}{|c|c|c|c|c|c|}
\hline \multicolumn{6}{|c|}{ sequence comparison (corresponding sequences to $a-85$ B epitopes) } \\
\hline Clone & $85 \mathrm{~A}$ & $85 \mathrm{~B}$ & $85 C^{*}$ & $85 \mathrm{D}$ & Expected cross reaction \\
\hline MFU50-A10 & KEDPAWQRNDPL & SSDPAWERNDPT & SSDPAWKRNDPM & SDPA & $85 \mathrm{~A}, 85 \mathrm{C}, 85 \mathrm{D}$ \\
\hline MFU50-C10 & SPALYL & SPAVYL & PHAVYL & PHAVYL & $85 \mathrm{~A}, 85 \mathrm{C}, 85 \mathrm{D}$ \\
\hline MFU50-D4 & AFSRPGLPV & AFSRPGLPV & AFSRPGLPV & - & $85 \mathrm{~A}, 85 \mathrm{C}$ \\
\hline MFU50-D7 & AFSRPGLPVEYL & AFSRPGLPVEYL & AFSRPGLPVEYL & - & $85 \mathrm{~A}, 85 \mathrm{C}$ \\
\hline MFU50-E2 & KEDPAWQRN & SSDPAWERN & SSDPAWKRN & SDPA & $85 \mathrm{~A}, 85 \mathrm{C}, 85 \mathrm{D}$ \\
\hline \multicolumn{6}{|c|}{ Reaction with 85 complex antigens in ELISA } \\
\hline Clone & $85 \mathrm{~A}$ & $85 B$ & $85 C^{*}$ & $85 \mathrm{D}$ & Determined cross reaction \\
\hline MFU50-A10 & Strong & Strong & - & Strong & $85 \mathrm{~A}, 85 \mathrm{D}$ \\
\hline MFU50-C10 & None & Strong & - & None & None \\
\hline MFU50-D4 & Weak & Strong & - & None & Weak $85 \mathrm{~A}$ \\
\hline MFU50-D7 & None & Weak & - & None & None \\
\hline MFU50-E2 & None & Weak & - & None & None \\
\hline
\end{tabular}

*Purified antigen $85 \mathrm{C}$ was not available for immunological assays, nevertheless it is listed for completeness of the illustration. 


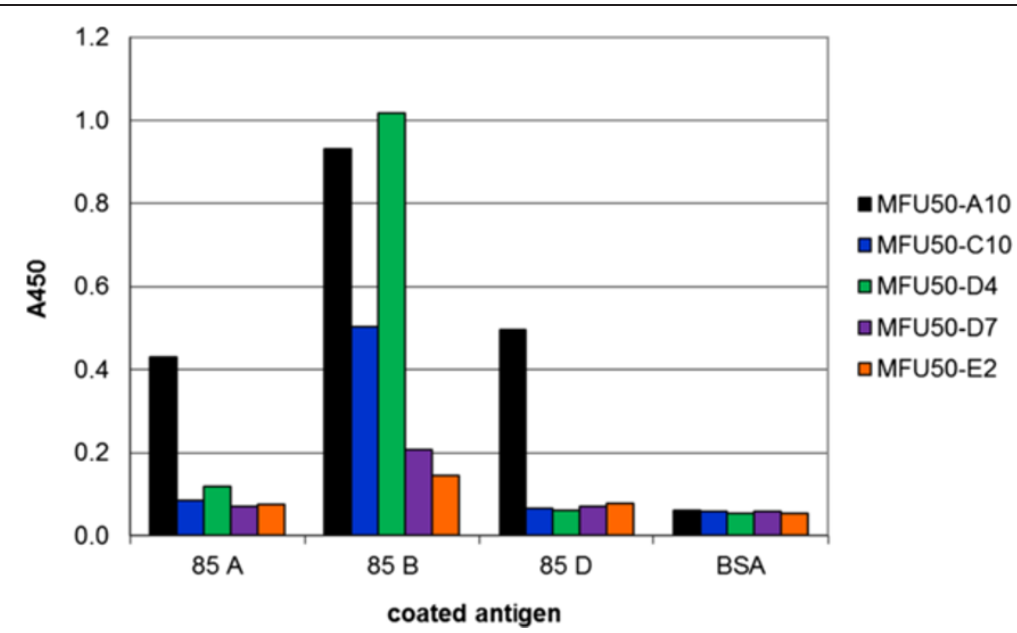

Figure 3 Cross reactions of a-85 B scFv-Fc with other 85 complex antigens in ELISA. 100 ng of the antigens were directly coated to the wells. 85 B detection with a-85 B scFv-Fc (using concentrations at half maximal saturation), detection of bound scFv-Fc with goat a-human IgG (FC)-HRP, development with TMB.

filtrate and Mtb/BCG cell extracts. The other antibodies bound only to recombinant $85 \mathrm{~B}$. A weak cross reaction of MFU50-A10 with 7H9 medium was detected.

\section{Development of a sandwich ELISA}

Due to the availability of five different antibodies with three different epitopes on the target antigen a sandwich $\alpha-85 \mathrm{~B}$ assay was performed. Therefore MFU50-A10 (epitope "SSDPAWERNDPT"), MFU50-C10 (epitope "SPAVYL") and MFU50-D4 (epitope "AFSRPGLPV") scFv-Fc were conjugated to HRP. Sandwich ELISA detection of the antigen was carried out with MFU50-A10-HRP, MFU50C10-HRP or MFU50-D4-HRP as detection antibodies. Capturing was conducted with corresponding antibodies recognizing different epitopes (than the detection antibody) on the target (Figure 5A, B, C). Blocking reagent only was used as a negative control $\left(\mathrm{A}_{450}=0.02-0.05\right)$. Sandwich detection of the recombinant antigen was successful with all combinations. The antigen detection limit for capturing with MFU50-A10, MFU50-C10, MFU50-D4 or MFU50D7 was determined to $\sim 10 \mathrm{ng} / \mathrm{mL}$, independent from the detection antibody. Capturing with MFU50-E2 resulted in a detection limit of $\sim 25 \mathrm{ng} / \mathrm{mL}$. The most suitable combination was obtained with MFU50-A10 as the capture antibody and MFU50-C10-HRP as detection antibodyconjugate. Mtb culture filtrate (Mtb cultivated in 7H9 + $\mathrm{ADC}+$ Tween for 3 months at $37^{\circ} \mathrm{C}$ ) was analysed by $\alpha-85$ $\mathrm{B}$ sandwich titration ELISA (Figure 6A, red curve). This resulted in weak binding barely distinguishable from the medium control (Figure 6A, pink curve). Mtb culture

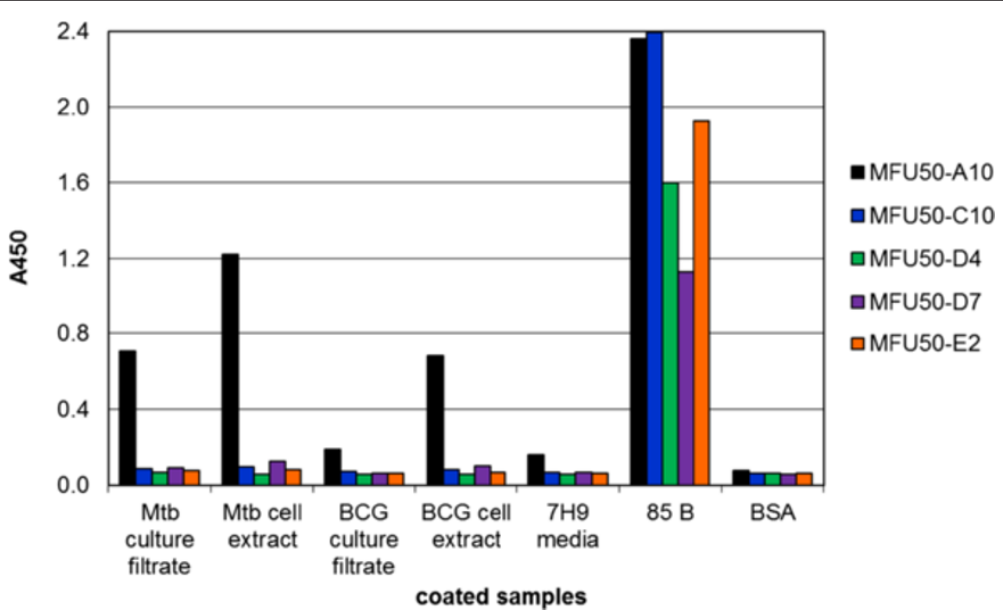

Figure 4 Reaction of a-85 B scFv-Fc with Mtb/BCG cell extracts and culture filtrates determined by indirect ELISA. $100 \mathrm{ng} / 100 \mu \mathrm{L}$ of the different samples were directly coated to the well, reaction was determined with a scFv-Fc concentration of $2.5 \mu \mathrm{g} / \mathrm{mL}$. Detection of bound scFv-Fc with goat a-human $\lg G(F c)-H R P$. Development with TMB. 


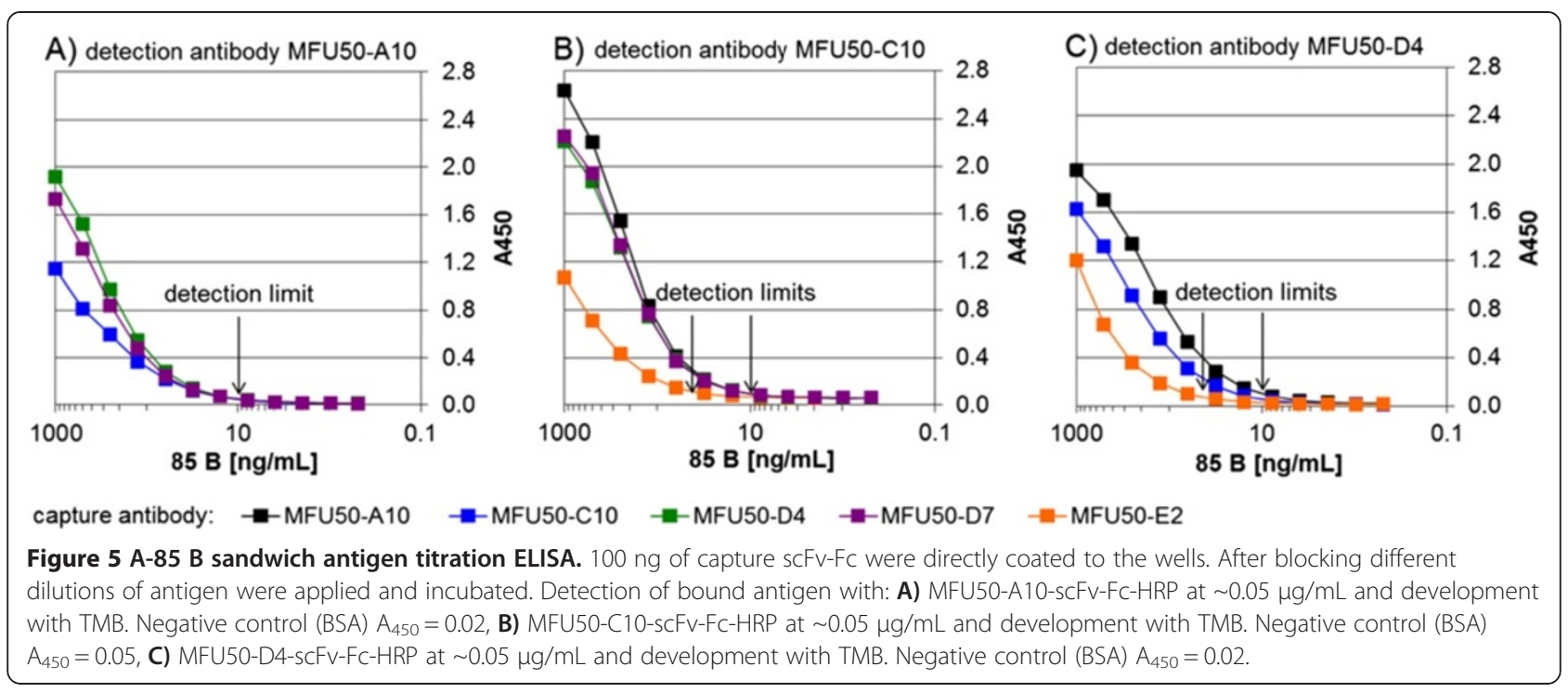

filtrate was further analysed by direct $\alpha-85$ B ELISA (Figure 6A, black curve). In this assay there was no increase of the signal by increasing of sample volume. Additionally, Mtb cell extract was analysed by $\alpha-85$ B sandwich titration ELISA (Figure 6B, red curve). This showed no binding distinguishable from the negative control except for the highest concentration (Figure 6B, grey curve). However, in a direct $\alpha-85$ B ELISA specific binding to Mtb cell extract was observed (Figure 6B, black curve).

\section{Effect of sample treatment on 85 B detection}

The failed detection of $85 \mathrm{~B}$ in Mtb cell extract in sandwich ELISA compared to the successful detection in direct ELISA was further analysed. It was hypothesized that the sample treatment, especially autoclaving, was the cause for differing antigen detection. Cell extracts were prepared by autoclaving at $121^{\circ} \mathrm{C}$ for $20 \mathrm{~min}$. The influence of sample pretreatment by heat on $85 \mathrm{~B}$ detection was investigated by direct ELISA (Figure 7). When $85 \mathrm{~B}$ was boiled, antigen binding was reduced. Further examination of the susceptibility of $85 \mathrm{~B}$ to heat was carried out by analytical SEC. The theoretical molecular mass of an $85 \mathrm{~B}$ monomer was computed with the ExPASy prot param tool [38] to $34.6 \mathrm{kDa}$. The untreated sample of 85 B displayed a small monomer peak at $33.8 \mathrm{kDa}$ and a dominant multimer peak with a molecular mass out of the measurement range but definitely greater than $669 \mathrm{kDa}$ (Figure 8A). In comparison the boiled $85 \mathrm{~B}$

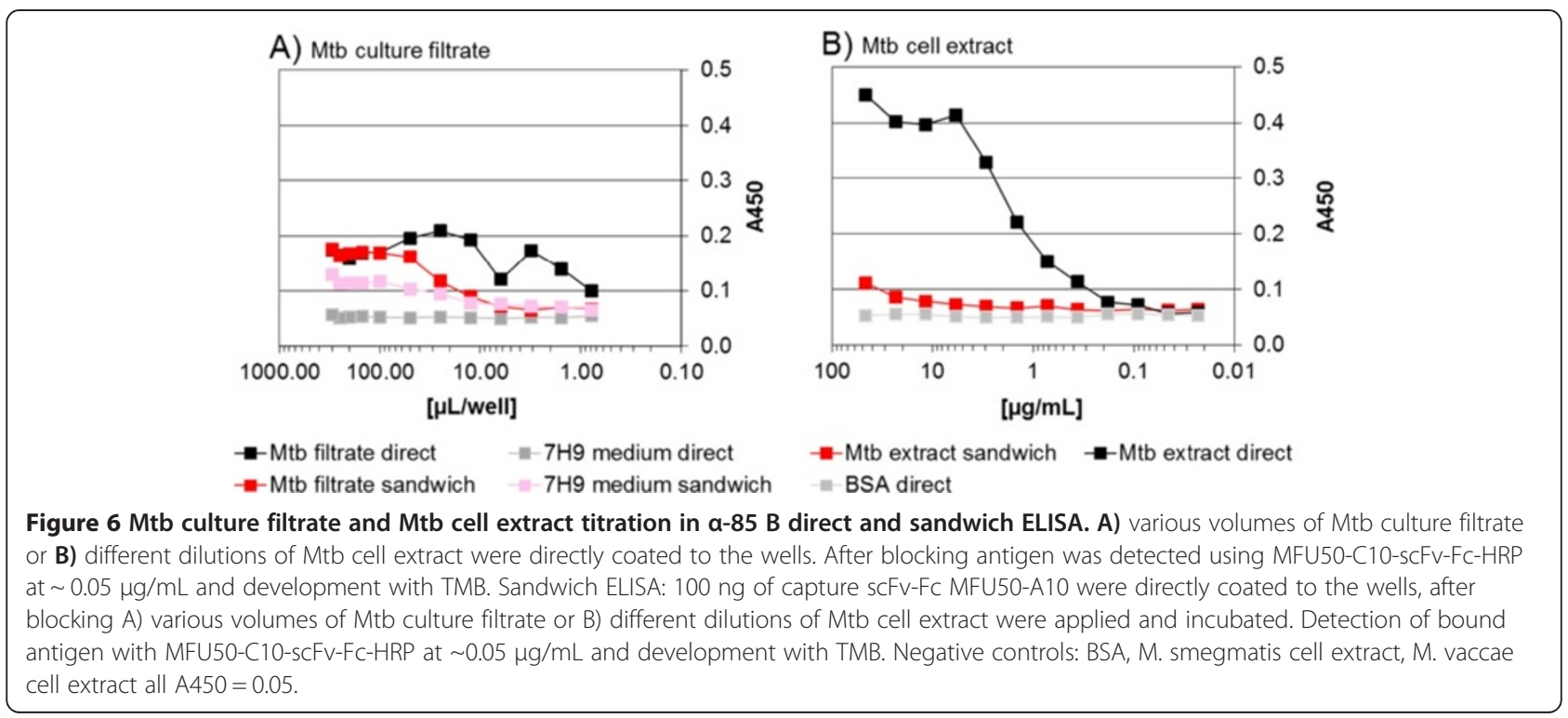




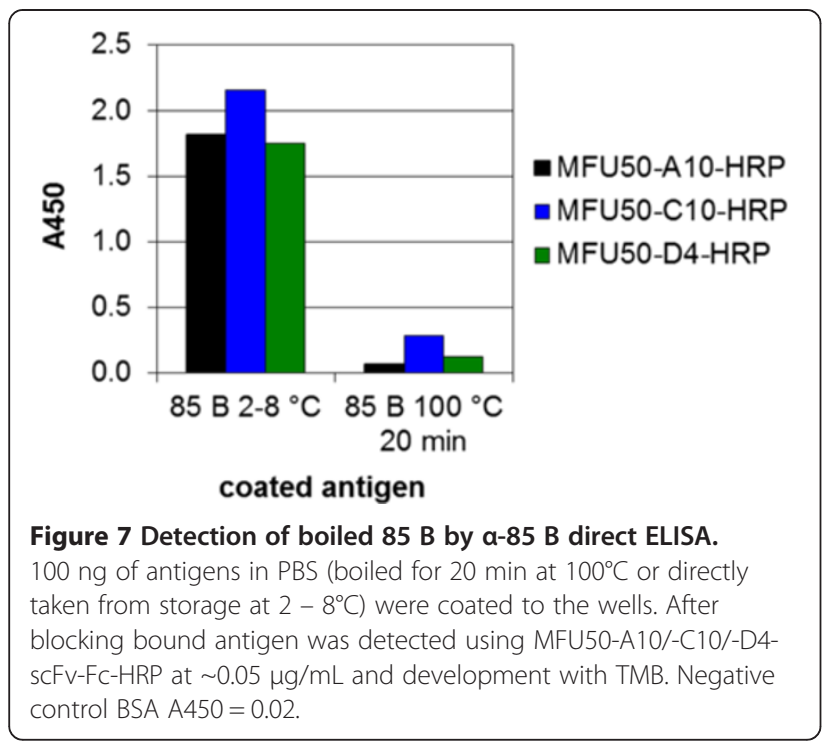

sample offered a dominant peak at the size of a monomer $(34.6 \mathrm{kDa})$, multiple peaks with lower molecular mass and a few non-dominant multimer peaks (Figure 8B). Interestingly, aggregation was greater in the untreated sample than in the boiled sample. It was concluded that the aggregation improved sandwich detection, and if multimers were detected by sandwich ELISA, the use of the same antibody for capturing and detection should be possible. Experimental study by sandwich ELISA (Figure 9) verified this assumption. In the untreated as well as in the boiled sample, sandwich detection with only one antibody was possible (Figure 9, arrows).

\section{Development of a lateral flow immuno assay}

To develop a Lateral Flow Immuno Assay (LFIA) all $\alpha$ $85 \mathrm{~B} \mathrm{scFv}-\mathrm{Fc}$ were conjugated to $40 \mathrm{~nm}$ colloidal gold. Sandwich 85 B detection was performed with all available antibodies for capturing and all antibody-gold conjugates for detection. The most suitable combination, MFU50-A10 as capture antibody and MFU50-D4-gold as detection antibody, was further analysed. A procedure that allowed sensitive antigen detection and low background combined with good feasibility was developed (data not shown). The $85 \mathrm{~B}$ detection limit was determined by sandwich LFIA to $\leq 5 \mathrm{ng} / \mathrm{mL}$ (Figure 10). Mtb cell extract or culture filtrate (concentrated and unconcentrated) were analysed by $\alpha-85 \mathrm{~B}$ sandwich LFIA. Unfortunately, $85 \mathrm{~B}$ was not detectable in any sample in this assay.

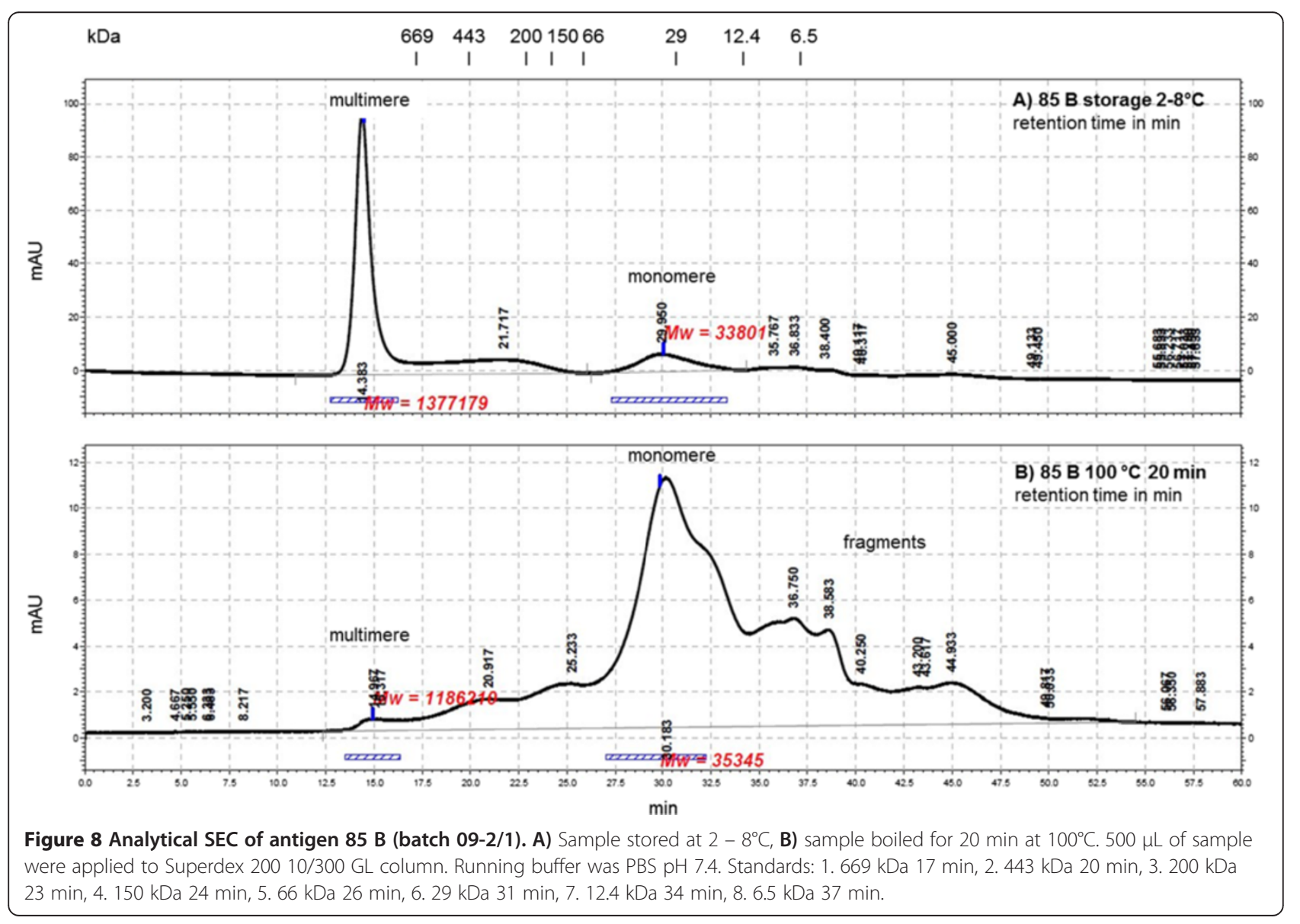




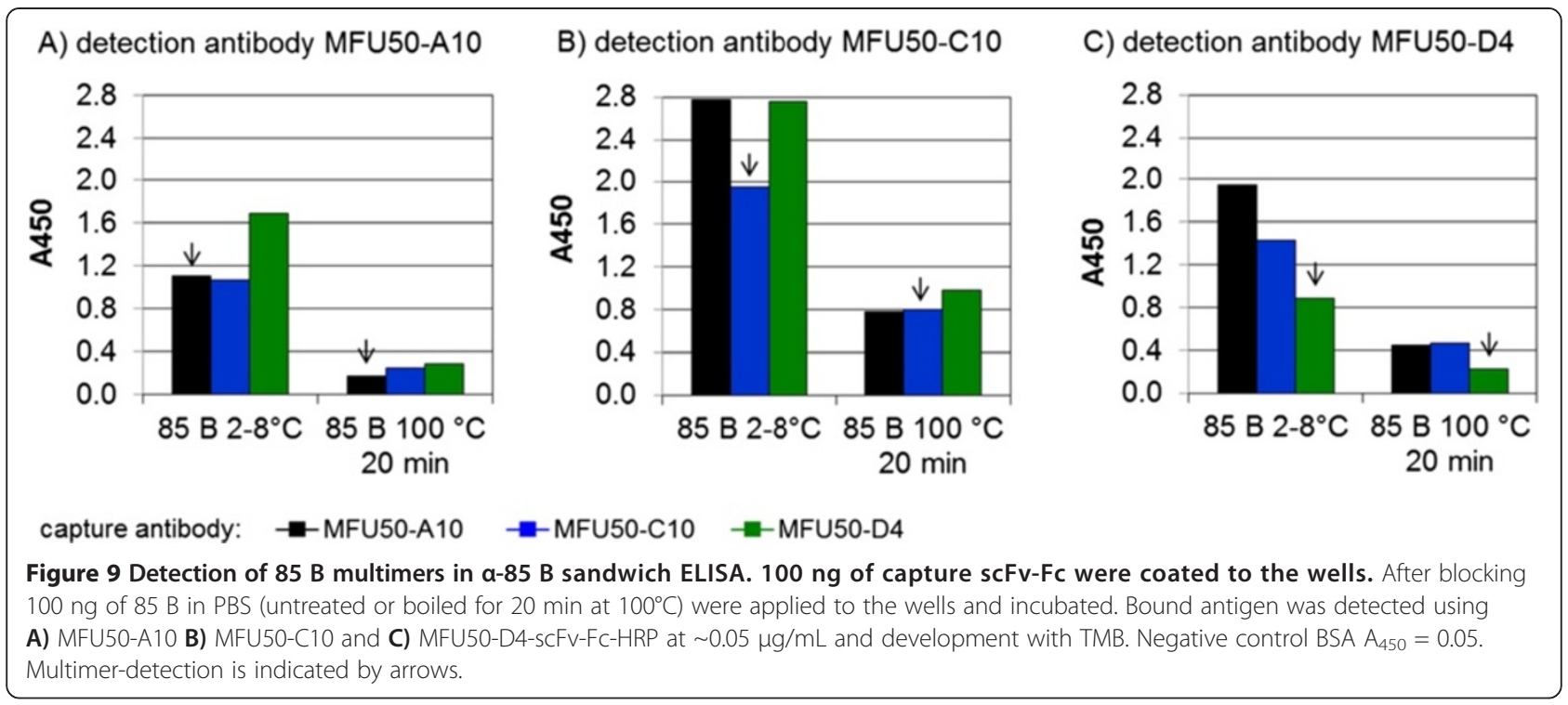

\section{Development of an immunoblot assay for the detection of $85 \mathrm{~B}$}

Sandwich detection of antigen 85 B in Mtb culture filtrates and cell extracts was complex in previously described sandwich ELISA and LFIA. As an alternative a direct $\alpha-85$ B immunoblot assay was developed to avoid the challenge of sample pretreatment in sandwich detection. Furthermore, Mtb was cultured in Sauton's minimal medium and culture filtrates were concentrated to increase the antigen quantity. Weekly samples were taken, concentrated 20 to 30 fold and analysed by reducing gel analysis via Tape Station and $\alpha-85$ B immunoblot. No 85 B was detected in 7 and 16 days old cultures by either means (data not shown). After 22 days a protein band at $\sim 30 \mathrm{kDa}$ (according to Tape Station analysis, Figure 11B) was recognized by MFU50-A10 in immunoblot (Figure 11A). Additionally, $85 \mathrm{~B}$ expression was found in 61 and 70 days old cultures (data not shown). The Tape Station and $\alpha-85$ B immunoblot results for 22 and 76 days old cultures are given in Figure 11.

\section{Discussion}

Tuberculosis is the leading cause of death due to bacterial infections worldwide [1]. State of the art TB detection

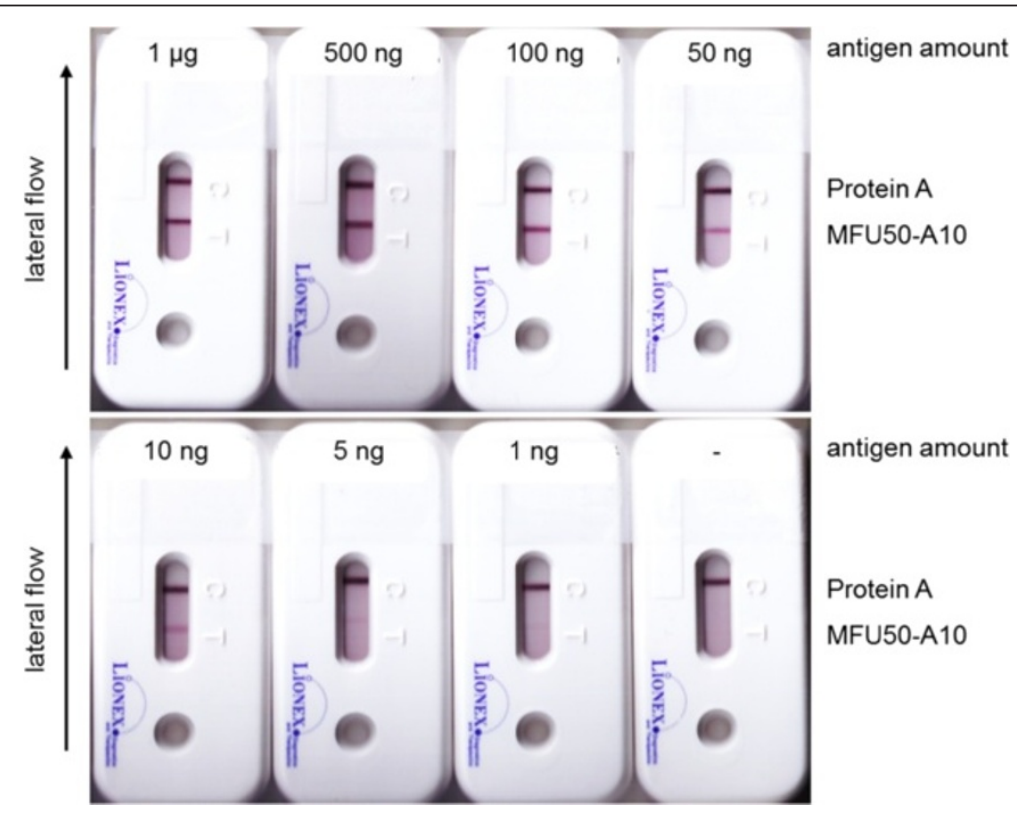

Figure 10 A-85 B sandwich LFIA, determination of detection limit. $100 \mu \mathrm{L}$ sample (7H9 medium spiked with 85 B) $+50 \mu \mathrm{L} 2.2 \mathrm{mM}$ borax pH 8.8 containing 8\% BSA were applied on sample pad, read out after 20 min. 


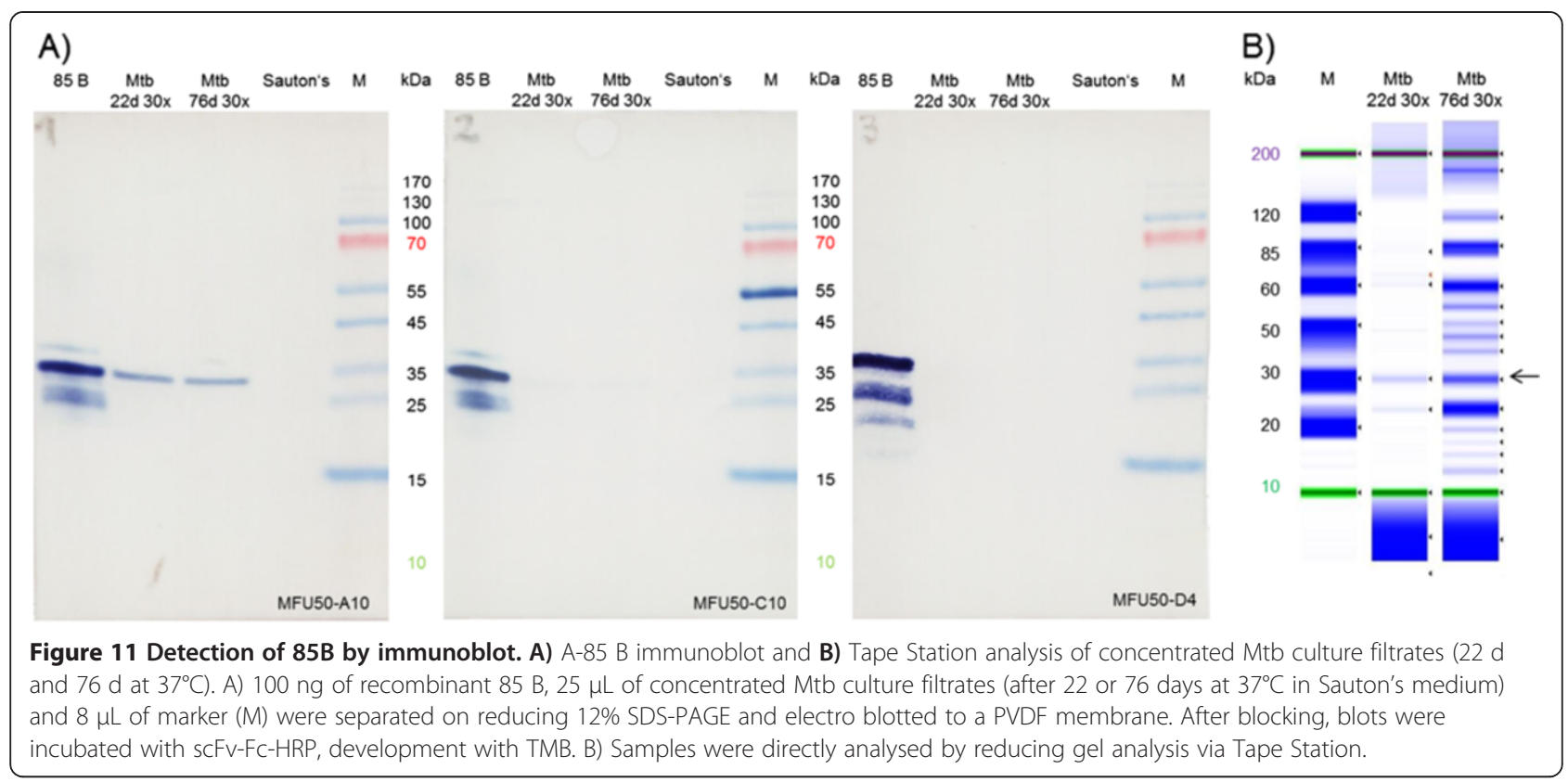

is mostly time consuming or needs expensive infrastructure [39]. In developing countries, a rapid, cheap and easy to use POC TB test is needed [9]. The WHO does not recommend the detection of antibodies against $\mathrm{Mtb}$ [10]. The only available assay for direct Mtb antigen detection is that against mycobacterial Lipoarabinomannan (LAM). However this test displays poor sensitivity apart from in patients with advanced HIV/AIDS [40].

In this work, we isolated and characterized specific antibodies against Mtb antigen $85 \mathrm{~B}$. These antibodies were proved suitable for $85 \mathrm{~B}$ sandwich detection in ELISA and LFIA. In addition, an Mtb immunoblot assay was developed.

Five unique antibodies were selected from the human naïve libraries HAL7/8 [33]. The examined antibodies displayed homogeneity in the subfamily of the variable gene segment of the heavy chain $\left(\right.$ all $V_{\mathrm{H}^{3}} 3$ ). This correlates with the overrepresentation of $\mathrm{V}_{\mathrm{H}} 1$ and $\mathrm{V}_{\mathrm{H}} 3$ in the HAL7/8 libraries [41] and in vivo [42]. Four antibodies have a lambda light chain, one a kappa light chain. According to Løset et al. [43] lambda scFv are expressed in higher yields in E. coli compared to kappa scFv, which may lead to an advantage in phage display $[33,41]$. The antibody MFU50-C10 has a germline combination of $\mathrm{V}_{\mathrm{H}} 3$ and $\mathrm{V}_{\mathrm{K}} 1$, which is common in vivo and in naïve libraries $[33,42,44]$. The lambda germline sequences present in the other antibodies are from the subfamilies 2, 3, 7 and 8 . Subfamilies V $\lambda 1,2$ and 3 are dominant in vivo, whereupon V $\lambda 7$ and 8 are rare in vivo [42,44]. In the HAL7 library $\mathrm{V} \lambda 7$ and 8 are more frequent than in vivo [33].

Ferrara et al. [22] selected 48 antibodies directed against the Mtb 85 complex in a combination of yeast and phage display. None of these antibodies were specific for an individual 85 antigen but, cross reacted with all other 85 complex proteins. Landowski et al. [45] isolated an $\alpha-85$ B chicken IgY which cross reacted with 85 complex proteins. Drowart et al. [21] generated seven monoclonal $\alpha-85$ complex antibodies, which all cross reacted with other mycobacterial species however none were specific for antigen $85 \mathrm{~B}$. This study shows the isolation of the first human recombinant antibodies (MFU50-C10, MFU50-D7 and MFU50-E2) specific for antigen 85 B. Furthermore four $\alpha$ 85 A antibodies (MFU12-D8, MFU53-A3, MFU53-F3 and MFU53-G2) and three $\alpha-85$ D antibodies (MFU51-A6, MFU51-B10 and MFU53-C2) were generated (unpublished data). MFU12 -D8 was found to be specific for antigen $85 \mathrm{~A}$ and MFU51-B10 was specific for $85 \mathrm{D}$. These antibodies allow for the discrimination between individual components of the 85 complex. Antibody phage display using human naive antibody gene libraries allows for the selection against non-immunogenic proteins and epitopes. We propose these epitopes, which would allow discrimination between the different 85 proteins, are not immunogenic. We propose this because of the fact that no antibodies, specific for one component of the 85 complex, were isolated by hybridoma technology $[21,23]$.

Easy applicability to in vitro assays was showed in this study by conjugation to colloidal gold or HRP. Due to the recombinant nature of the explored antibodies, they can easily be altered to different formats, fused to different Fc-parts [34] or fused to markers such as green fluorescent protein (GFP, [46]) for in vivo experiments. Thereby the role of particular 85 proteins in Mtb cell wall biosynthesis and evasion of the host's immune response may be investigated. 
All antibodies generated in this study recognized continuous sequences of the antigen, and the corresponding epitopes were determined by screening overlapping peptides immobilized on a cellulose membrane. MFU50-D4 recognized the epitope "AFSRPGLPVEYL" and MFU50D7 recognized the epitope "AFSRPGLPV". This epitope region seems to be a potent $\mathrm{T}$ cell antigen since synthetic peptides including this sequence were found to induce cytokine release or immune cell proliferation in peripheral blood of individuals with varying TB status [47-50]. However only weak human B cell responses against these peptides were reported [49,51]. Interestingly, no antibodies against this epitope were generated by immunization. In this work, human antibodies were successfully generated by screening phage display libraries, fortifying the advantage of phage display technology over conventional immunization methods. Protein sequence comparison of the 85 complex proteins revealed the presence of the epitope in antigen $85 \mathrm{~A}$ and $85 \mathrm{C}$, suggesting cross reactivity. In ELISA and immunoblot analysis MFU50-D7 showed no 85 A binding, however MFU50-D4 showed slight cross reactivity with 85 A. During this study $85 \mathrm{C}$ was not available for examination. Furthermore, a protein blast search (BLASTP, [52]) disclosed the existence of the entire epitope in several different mycobacterial strains (i.e. M. bovis, M. ulcerans, M. marinum, M. smegmatis, $M$. vaccae, etc.), suggesting cross reactivity.

The $\alpha-85$ B antibodies MFU50-A10 and MFU50-E2 recognize the epitopes "SSDPAWERNDPT" and "SSDPAWERN" respectively. Landowski et al. [45] generated an oligoclonal chicken IgY antibody against the peptide "SSDPAWERNDPT" (epitope ID 60953, IEDB) and demonstrated 55\% sensitivity and $85 \%$ specificity for detection of circulating $85 \mathrm{~B}$ in human blood by an immunoblot approach. Shen et al. [51] reported the synthetic peptide “GPSSDPAWERNDPTQ QIPKL" (epitope ID 21797, IEDB) was recognized by sera (IgG) of TB + individuals. Similar peptides containing the epitope "SSDPAWE RNDPT" were found to induce cytokine release or $\mathrm{T}$ cell proliferation in various assays with samples of $\mathrm{TB}+$ individuals $[49,50,53-55]$. The entire amino acid sequence "SSDPAWERNDPT" is present only in $85 \mathrm{~B}$ of $M$. tuberculosis and M. bovis BCG. Homologous sequences in Mtb $85 \mathrm{~A}$ or $85 \mathrm{C}$ and in 85 complex proteins from other mycobacterial species (identified by BLASTP) differed primarily by substitution of one amino acid. Cross reactivity of MFU50-A10 with Mtb $85 \mathrm{~A}$ and $M$. bovis BCG cell extract and culture filtrate was detected by indirect ELISA and immunoblot. Landowski et al. [45] found a "SSDPAWERNDPT" specific chicken IgY antibody to be cross reactive with Mtb $85 \mathrm{~A}$ and $85 \mathrm{C}$ as well as 85 complex proteins of $M$. avium. The reaction of MFU50-A10 with 85 A, B and D indicates a possible smaller epitope than determined by epitope mapping. The amino acid sequence "DPA" is present in antigen $85 \mathrm{~A}, \mathrm{~B}$ and $\mathrm{C}$, but the adjacent amino acids differ. In $85 \mathrm{~B}$ the "DPA" is flanked by serine on the N-terminal site and tryptophan on the C-terminal site ("SDPAWE"). In $85 \mathrm{~A}$ glutamic acid is $\mathrm{N}$-terminal and tryptophan $\mathrm{C}$-terminal ("EDPAWQ"). In $85 \mathrm{D}$ serine is N-terminal and alanine C-terminal ("SDPAAM"). It seems possible that the epitope of MFU50-A10 is "SDPAW" or "DPAWE", which would mean that two amino acids are different in $85 \mathrm{~A}$ or $85 \mathrm{D}$ respectively. This would explain the weaker recognition of $85 \mathrm{~A}$ and $85 \mathrm{D}$. Furthermore, the comparison of the $3 \mathrm{D}$ structures of antigen $85 \mathrm{~A}$ and $85 \mathrm{~B}$ (Figure 12) revealed that the glutamic acid in $85 \mathrm{~B}$ forms a pin structure in front of the "DPAW" region. This formation is missing in $85 \mathrm{~A}$, instead of glutamic acid there is glutamine. Glutamic acid can mediate strong electrostatic attractions and hydrogen bridges through the loaded carboxylgroup, whereupon glutamine is uncharged and can only mediate hydrogen bridges through the amino- and the ketogroup [56]. Thus, it is reasoned that the glutamic acid pin structure is needed structurally for correct docking, and physico-chemically for full strength binding to the antigen.

MFU50-C10 recognizes the epitope "SPAVYL", which is close to the suggested active site of antigen $85 \mathrm{~B}$ [36], offering a possible inhibitory effect by steric hindrance [57]. Synthetic peptides including this epitope were found to induce cytokine release and $\mathrm{T}$ cell proliferation in peripheral blood mononuclear cells of $\mathrm{TB}+$ humans $[49,50,54,58]$ and antibodies against these peptides were detected in sera of TB + individuals [51,59]. Sequence comparison of Mtb 85 complex proteins revealed no homology in this area. According to BLASTP equivalent sequences are present in several other mycobacterial species (i.e. M. bovis, M. marinum, M. leprae, M. vaccae, $M$. ulcerans, $M$. avium, etc.). No cross reactivity with 85 $\mathrm{A}$ and $85 \mathrm{D}$ was detected by indirect ELISA and immunoblot, suggesting specificity for antigen 85 B. Surprisingly, no cross reactions with $M$. bovis BCG cell extract and culture filtrate were detected in an indirect ELISA.

Sandwich ELISA detection of recombinant $85 \mathrm{~B}$ with the $\alpha-85$ B Yumabs was successful in all performed assays. The most suitable combination was capturing with MFU50-A10 and detection with MFU50-C10-HRP, reaching a detection limit of $\sim 10 \mathrm{ng} / \mathrm{mL}$. Sandwich LFIA detection of recombinant $85 \mathrm{~B}$ was successful capturing with MFU50-A10 and detecting with MFU50-D4-gold. A detection limit of $5 \mathrm{ng} /$ strip $(0.03 \mathrm{ng} / \mathrm{mL})$ was evaluated. There are no published reports on single antigen $85 \mathrm{~B}$ sandwich detection, only whole 85 complex sandwich assays [20,22-24,39,45,60].

Sandwich detection of recombinant 85 B was enhanced by multimeric antigen conformation, and reduced by 
85 A) DPAWQ

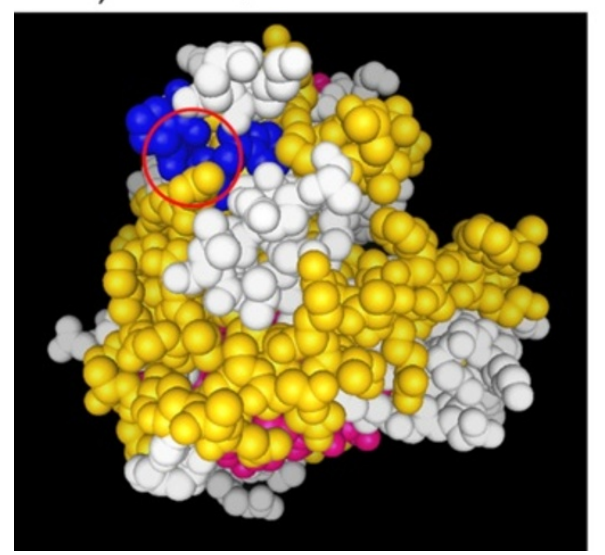

85 B) DPAWE

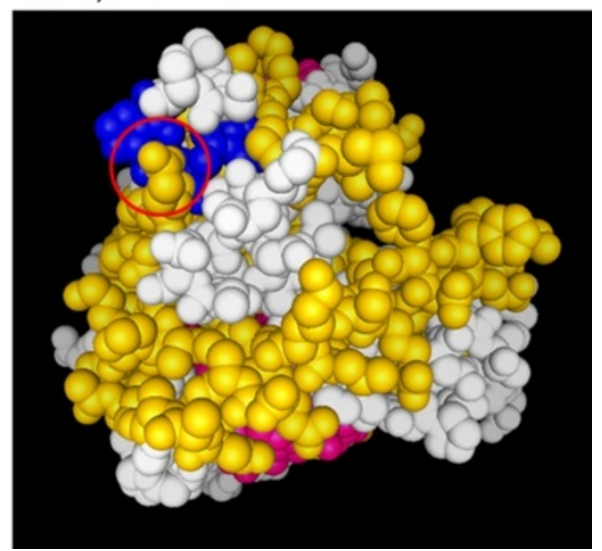

Figure 123 D structures of antigens A) 85 A and B) 85 B around the amino acid sequence “DPAW". A) Pdb1sfr (Resolution $2.7 \AA$, [75]) and B) Pdb1f0n (Resolution $1.9 \AA$, [36]) were modified with 3D molecule viewer (Invitrogen). Respectively only protein chain A is shown, atoms are displayed as space filling balls, "DPAW" is marked in blue, glutamic acid in 85 B is encircled in comparison to glutamine in $85 \mathrm{~A}$.

monomeric antigen conformation. The small size of the antigen ( $5 \mathrm{~nm}$ diameter, [36]) may be responsible for this finding. Considering the length of a human $\mathrm{scFv}$ of $~$ $4.5 \mathrm{~nm}$ [37] and the Fc-mediated homodimerisation of scFv-Fc fusions [34,61], sterical inhibition by the capture antibody is possible. The commercially available immunochromatographic assays for MPT64 antigen detection in Mtb cultures are sandwich assays with monoclonal antibodies [62]. The Capilia TB Test Kit [63] uses only one monoclonal antibody for a sandwich assay, indicating multimer detection. Recombinant antigen MPT64 showed multimerization by disulphide bonds in two unrelated studies $[64,65]$ and no difference in immunogenicity compared to native antigen $[64,66]$. These findings imply multimerization of native MPT64 and that these aggregates are detected in sandwich assays. Detection of $85 \mathrm{~B}$ in culture filtrates was only possible with MFU50-A10 in direct ELISA and immunoblot. MFU50-A10 was cross reactive with $85 \mathrm{~A}$ and $85 \mathrm{D}$ in ELISA and immunoblotting. It has been reported to cross react with $85 \mathrm{C}$ by Landowski et al. [45].

\section{Conclusions}

This work identifies the first recombinant human scFv antibodies specific for antigen $85 \mathrm{~B}$ selected by phage display from naïve antibody gene libraries (HAL7/8). These antibodies allow the discrimination between 85 complex proteins, and showed suitability for the establishment of different assays for Mtb 85 B detection. Antigen conformation influenced by sample treatment was shown to be important. The presented antibodies are candidates for the future development of a POC TB diagnostic kit. However, for this purpose an affinity maturation of the antibodies would be necessary to improve the sensitivity.

\section{Material and methods}

All chemicals used were p.a. purity grade and purchased from Sigma Aldrich, Merck or Carl Roth (all located in Germany) or as indicated otherwise.

\section{Antigen purification}

Genes fbpA, B, D coding for proteins of antigen 85 complex of $M$. tuberculosis were amplified by PCR and inserted into pET expression vectors (Novagen, Germany) by site directed cloning (Table 3).

Exchanges L78Q and S196T within the derived amino acid sequence of $85 \mathrm{~B}$, and exchange F54L within $85 \mathrm{C}$ were detected by DNA sequencing.

Recombinant 85A was produced in E. coli strain BL21 (DE3) [pLysS] (Novagen, Germany) by growth in LB [67] containing $400 \mu \mathrm{g} / \mathrm{mL}$ ampicillin and $34 \mu \mathrm{g} / \mathrm{mL}$ chloramphenicol. Expression was induced by addition of $1 \mathrm{mM}$ IPTG at mid-log-phase. Cells were harvested 4 hours after induction. $85 \mathrm{~B}$ and $85 \mathrm{C}$ were produced using BL21(DE3) (Novagen, Germany) as host strains grown in LB containing $50 \mu \mathrm{g} / \mathrm{mL}$ kanamycin. After induction with $1 \mathrm{mM}$ IPTG at mid-log-phase, cells were incubated overnight and then harvested.

Table 3 Cloned genes of M. tuberculosis antigen 85 complex and properties of the recombinant gene products

\begin{tabular}{lllll}
\hline Gene & Vector & \multicolumn{4}{l}{ Gene product } \\
\hline fbpA (Rv3804c) & pET26b & Antigen & Signal sequence & His-tag \\
fbpB (Rv1886c) & pET22b & $85 \mathrm{~B}$ & Yes & N-terminal \\
fbpD (Rv3803c) & pET28c & $85 \mathrm{D}$ & Yes & no \\
\hline
\end{tabular}




\section{B purification}

Cells were suspended in $10 \mathrm{mM}$ tris/ $\mathrm{HCl}, \mathrm{pH} 8.0$ containing $1 \%$ Triton $\mathrm{X}-100$ and $10 \mathrm{mM}$ EDTA $(10 \mathrm{~mL}$ per g wet weight). After cell disruption by sonification and centrifugation the pellet was washed once using the same buffer. The pellet was denatured in $20 \mathrm{mM}$ tris/ $\mathrm{HCl}, \mathrm{pH} 8.0,1 \%$ Triton X-100 buffer containing $8 \mathrm{M}$ urea and $2 \mathrm{mM}$ DTT.

After centrifugation the supernatant containing the denatured 85 B antigen was bound on a Q-Sepharose High Performance column (GE Healthcare) and eluted by a linear gradient from 0 to $500 \mathrm{mM} \mathrm{NaCl}$. Fractions containing $85 \mathrm{~B}$ antigen were pooled and underwent a buffer exchange step on a Sephadex G25 fine column (GE Healthcare) into the buffer described above without Triton X-100. The protein containing pool was subjected to another chromatography step on a Q-Sepharose High Performance column (GE Healthcare). Again protein elution was performed by a linear gradient from $0-500 \mathrm{mM}$ $\mathrm{NaCl}$. Pure antigen $85 \mathrm{~B}$ containing fractions were pooled and underwent a final refolding and buffer exchange step on a Sephadex G25 fine column (GE Healthcare) into $10 \mathrm{mM} \mathrm{NH}_{4} \mathrm{HCO}_{3}, 100 \mu \mathrm{M}$ DTT, pH 7,9.

The final protein preparation is a mixture of protein containing the signal sequence and lacking the signal sequence. Approximately $90 \%$ of the protein shows the signal sequence and approximately $10 \%$ lacks the signal sequence.

\section{A purification}

Cells were suspended in $20 \mathrm{mM}$ tris/ $\mathrm{HCl}, 100 \mathrm{mM} \mathrm{NaCl}$, pH 8.0 (10 mL per gram wet weight). After cell disruption by sonification and centrifugation, imidazole was added to the supernatant to a final concentration of $5 \mathrm{mM}$. This solution was applied on a Ni-NTA Superflow column (GE Healthcare) and eluted by a linear gradient from 0 to $500 \mathrm{mM}$ imidazole. Fractions containing 85 A antigen were pooled and underwent a buffer exchange step on a Sephadex G25 fine column (GE Healthcare) into $20 \mathrm{mM}$ tris/HCl, pH 8.0. Chromatography using a Q-Sepharose High Performance column (GE Healthcare) was performed on the pooled protein sample. Protein elution was performed using a linear gradient from $0-500 \mathrm{mM} \mathrm{NaCl}$. Pure antigen 85 A containing fractions were pooled and underwent a final buffer exchange step on a Sephadex G25 fine column (GE Healthcare) into $10 \mathrm{mM} \mathrm{NH} \mathrm{NCO}_{3}$, $\mathrm{pH} 7.9$.

\section{D purification}

Cells were suspended in $20 \mathrm{mM}$ tris/ $\mathrm{HCl}, 100 \mathrm{mM} \mathrm{NaCl}$, pH 8.0 containing $1 \%$ Triton $\mathrm{X}-100(10 \mathrm{~mL}$ per gram wet weight). After cell disruption by sonification and centrifugation the pellet was washed once using $20 \mathrm{mM}$ tris/ $\mathrm{HCl}, 100 \mathrm{mM} \mathrm{NaCl}$ pH 8.0 containing 1\% Triton X100. Afterwards the pellet was denatured in $20 \mathrm{mM}$ tris/
$\mathrm{HCl}, 100 \mathrm{mM} \mathrm{NaCl}$, pH 8.0 containing $8 \mathrm{M}$ urea. After centrifugation the supernatant containing the denatured $85 \mathrm{D}$ antigen underwent a refolding step on a Sephadex G25 fine column (GE Healthcare) into $20 \mathrm{mM}$ tris/ $\mathrm{HCl}$, $100 \mathrm{mM} \mathrm{NaCl}, \mathrm{pH}$ 8.0. The protein peak of this refolding step was collected and then bound on a Q-Sepharose High Performance column (GE Healthcare). Protein elution was performed by a linear gradient from 0 to $300 \mathrm{mM} \mathrm{NaCl}$. Fractions containing pure $85 \mathrm{D}$ antigen were pooled and underwent a buffer exchange step on a Sephadex G25 fine column (GE Healthcare) into $10 \mathrm{mM} \mathrm{NH}_{4} \mathrm{HCO}_{3}, \mathrm{pH}$ 7,9. For final endotoxin removal the protein solution was passed four times over a $1 \mathrm{~mL}$ Profos endotrap red column (Hyglos $\mathrm{GmbH})$.

\section{Selection of human antibodies using phage display}

$\mathrm{ScFv}$ were isolated in vitro from the human naïve phage libraries HAL7/8 by panning on decreasing amounts (10, 3 and $1 \mu \mathrm{g}$ ) of immobilized recombinant antigen $85 \mathrm{~B}$ according to [68].

\section{Production of soluble scFv antibodies for screening ELISA}

The identification of monoclonal binders was performed as described in [69] with the following modifications: 96-well polypropylene (PP) micro titer plates (Greiner, Germany) containing $150 \mu \mathrm{L} 2 \mathrm{xYT}-\mathrm{G} / \mathrm{A}$ (2xYT [67] supplemented with $100 \mathrm{mM}$ glucose and $100 \mu \mathrm{g} / \mathrm{mL}$ ampicillin) were inoculated with colonies from the titration plate of the third panning round. Micro titer plates (MTP) were incubated overnight at $37^{\circ} \mathrm{C}$ and $850 \mathrm{rpm}$ in a MTP shaker (PST-60HL-4, Lab4you, Austria). A volume of $180 \mu \mathrm{L} 2 \mathrm{xYT}-\mathrm{G} / \mathrm{A}$ per well in PP-MTP was inoculated with $10 \mu \mathrm{L}$ of the overnight culture and grown at $37^{\circ} \mathrm{C}$ and $850 \mathrm{rpm}$ for two hours. Bacteria were harvested by centrifugation for $10 \mathrm{~min}$ at 3,220 $\times \mathrm{g}$ and $180 \mu \mathrm{L}$ supernatant were removed. The pellets were resuspended in $180 \mu \mathrm{L} 2 \mathrm{xYT}$ supplemented with $50 \mathrm{mM}$ sucrose and $100 \mu \mathrm{g} / \mathrm{mL}$ ampicillin $+50 \mu \mathrm{M}$ IPTG and incubated at $30^{\circ} \mathrm{C}$ and $850 \mathrm{rpm}$ overnight. Bacteria were pelleted by centrifugation for $15 \mathrm{~min}$ at $3,220 \times \mathrm{g}$ and $4^{\circ} \mathrm{C}$. The scFv-containing supernatant was transferred to a new PP-MTP and stored at $4^{\circ} \mathrm{C}$ prior to analysis.

\section{Screening ELISA}

96 wells of Microlon MTP (Greiner, Germany) were coated with $100 \mathrm{ng}$ of recombinant $85 \mathrm{~B}$ in $100 \mu \mathrm{L}$ PBS buffer pH 7.4 or BSA in $100 \mu \mathrm{L}$ PBS buffer pH 7.4 (Carl Roth, Germany) as a negative control [67] overnight at $4^{\circ} \mathrm{C}$. After coating, the wells were blocked with $300 \mu \mathrm{L}$ PBST-B (PBS supplemented with $0.1 \%(w / v)$ Tween-20 and $1 \%(\mathrm{w} / \mathrm{v}) \mathrm{BSA}$ ) for $2 \mathrm{~h}$ at RT. This was followed by three washing steps with PBST0.05 (PBS supplemented with $0.05 \%(\mathrm{w} / \mathrm{v})$ Tween-20). For identification of binders, supernatants containing monoclonal scFv were incubated 
in the antigen coated plates for $1.5 \mathrm{~h}$ at RT followed by three PBST washing cycles. Bound $\mathrm{scFv}$ were detected using mouse $\alpha$-c-Myc-tag 9E10 (culture supernatant, $100 \mu \mathrm{L}, 1: 1,000$ in PBST-B; $1.5 \mathrm{~h}$ at RT) followed by goat $\alpha$-mouse IgG (Fc)-HRP (A0168, Sigma-Aldrich, Germany) $(100 \mu \mathrm{L}, 1: 30,000$ in PBST-B; $45 \mathrm{~min}$ at RT). After three washing steps with PBST0.05 the reactions were visualized with $100 \mu \mathrm{L}$ 3,3,5,5'-tetramethylbenzidine (TMB, Seramun, Germany) as a substrate. The staining reaction was terminated by addition of $100 \mu \mathrm{L} 0.2 \mathrm{M} \mathrm{H}_{2} \mathrm{SO}_{4}$. Absorbance at $450 \mathrm{~nm}$ (620 nm reference) was measured using MRX ELISA reader (Dynatec, Germany).

\section{Antibody titration ELISA}

For each antibody, 24 wells of Greiner Microlon MTP were coated with $100 \mathrm{ng}$ antigen in $\mathrm{PBS}$ at $4^{\circ} \mathrm{C}$ overnight. BSA was coated as a negative control. After coating, the wells were blocked with PBST-B for $2 \mathrm{~h}$ at RT, followed by three washing steps with PBST0.05. Twelve dilutions of antibody (differing, depending on the antibody) in PBST-B were applied in duplicates on the antigen and BSA controls and incubated for $1.5 \mathrm{~h}$ at RT. Bound scFv-Fc were detected using goat $\alpha$-human IgG (Fc)-HRP (A0170, Sigma-Aldrich, Germany) (100 $\mu \mathrm{L}, 1: 130,000$ in PBST-B; 45 min at RT). The assay was further processed as described above.

\section{Antigen titration ELISA}

Antigen in PBS at twelve dilutions $(1 \mu \mathrm{g} / \mathrm{mL}$ to $0.5 \mathrm{ng} /$ $\mathrm{mL}$ ) were coated in duplicates to wells of Greiner Microlon MTP at $4^{\circ} \mathrm{C}$ overnight. BSA coated wells were used as a negative control. After coating, the wells were blocked with PBST-B for $2 \mathrm{~h}$ at RT, followed by three washing steps with PBST. Antigen detection was carried out with a concentration of antibody at half maximal saturation (determined by antibody titration ELISA) in PBST-B for $1.5 \mathrm{~h}$ at RT followed by three PBST washing cycles. Bound scFv-Fc were detected using goat $\alpha$-human IgG (Fc)-HRP $(100 \mu \mathrm{L}, 1: 130,000$ in PBST-B; $45 \mathrm{~min}$ at $\mathrm{RT}$ ). The assay was further processed as described above.

\section{Direct ELISA}

Analyte (antigen or antibody) was coated to the surface of Greiner Microlon 96 Well MTP at various concentrations in PBS buffer overnight at $4^{\circ} \mathrm{C}$. Detection of antigen was carried out with an scFv-Fc antibody conjugated to HRP (by EZ-Link Plus Activated Peroxidase Kit, Pierce, Germany, according to the manufacturer's instructions) diluted in PBST-B for $1 \mathrm{~h}$ at RT. Detection of antibody was carried out with Goat a-human IgG (Fc)-HRP diluted $(100 \mu \mathrm{L}, 1: 130,000$ in PBST-B) $45 \mathrm{~min}$ at RT. The assay was further processed as described above.

\section{Sandwich antigen titration}

$100 \mathrm{ng}$ of capture antibodies were coated to the surface of 96 wells of Greiner Microlon MTP in PBS buffer overnight at $4{ }^{\circ} \mathrm{C}$. After coating, the wells were blocked with PBST-B for $2 \mathrm{~h}$ at RT, followed by three washing steps with PBST. Twelve dilutions of antigen in PBST-B were applied in duplicates onto the antibody coated wells and incubated for $1.5 \mathrm{~h}$ at RT, followed by three washing steps with PBST. Detection of bound antigen was performed with HRP conjugated scFv-Fc (exact dilutions described in results) in PBST-B for $1.5 \mathrm{~h}$ at RT, followed by three washing steps with PBST. The assay was further processed as described above.

\section{Epitope Mapping}

The protein sequence of 85 B (Rv1886c, UniProt ID P0C5B9, sequence source: http://genolist.pasteur.fr/ TubercuList/) was divided into overlapping peptide fragments, each consisting of 15 amino acids, with an offset of three amino acids. This array of peptides was synthesized by the SPOT technique [70,71] on an aminopegylated cellulose membrane (AIMS Scientific Products $\mathrm{GmbH}$, Wolfenbüttel, Germany) as described previously [72]. Peptides are N-terminally acetylated and remain covalently attached to the membrane via their carboxyterminus. The membrane bound peptide array was probed with the $\alpha-85 \mathrm{~B}$ antibodies for binding according to established procedures [30,72].

\section{Immunoblot}

Proteins were separated on 12\% SDS-PAGE $[73,74]$ and semi-dry blotted onto polyvinylidene fluoride (PVDF) membranes (Carl Roth, Germany) according to the manufacturer's instructions. Blocking was performed with MPBST (PBST0.1 supplemented with 2\% (w/v) dry milk) for minimum 30 min at RT. Subsequent incubation with protein-specific antibody was carried out in MPBST for a minimum of $60 \mathrm{~min}$ at RT. Three washing steps with PBST0.1 for 5 min were performed. The PVDF membrane was incubated with a secondary antibody coupled to HRP in MPBST for at least $45 \mathrm{~min}$ at RT. The blot was washed another three times with PBST0.1 and then developed with TMB peroxidase membrane substrate (Seramun, Germany) until an adequate signal was obtained. Development was stopped by three short washing steps with deionized water.

\section{LFIA assembly + execution}

$5-40 \mu \mathrm{L} \mathrm{cm}^{-1}$ of colloidal gold-antibody conjugates were dispensed onto $8 \mathrm{~mm}$ glass fibre pads (Millipore, Germany) using the xyz-dispenser (Biodot, USA) and dried at $37^{\circ} \mathrm{C}$. $1 \mu \mathrm{L} \mathrm{cm}{ }^{-1}$ of different concentrations of capture antibody solution (sandwich assay) or antigen (direct assay) in PBS were dispensed in a line onto Unisart CN 95 nitrocellulose 
membranes (20 mm, Sartorius, Germany) that were already assembled onto $300 \mathrm{~mm}$ backing cards (Jieyi Biotechnology, China), and dried at $37^{\circ} \mathrm{C}$. The glass fibre conjugate pads were laminated onto the backing cards, overlapping the nitrocellulose membrane at the connection point for $\sim 0.5-1 \mathrm{~mm}$. Then cellulose fibre pads (Millipore, Germany) were laminated onto the backing cards as sample and wicking pad, overlapping the nitrocellulose membrane at the connection point for $\sim 0.5-1 \mathrm{~mm}$. The assembled cards were cut into strips of $0.4 \mathrm{~cm}$ width with the CM4000 guillotine-cutter (Biodot) and the test strips were placed into Lateral Flow Strip Test (LFST) cassettes (Jieyi Biotechnology, China).

Several experiments were carried out to determine a procedure that would allow sensitive antigen detection and a low background combined with good feasibility (data not shown). The best option for a manageable LFIA was to add a diluent to the sample before applying it to the sample well. Therefore $1 / 3$ sample volume $(50 \mu \mathrm{L})$ of conjugation buffer ( $2 \mathrm{mM}$ borax $\mathrm{pH} 8.8$ ) enriched with $8 \%(\mathrm{w} / \mathrm{v})$ BSA were mixed with $100 \mu \mathrm{L}$ sample and applied to the LFIA. After $15-20$ min results were optically evaluated.

\section{Yumab production + purification}

All scFv isolated from antibody-phage display were subcloned into pCSE2.5-hIgG1-Fc-XP and produced as scFvFc (yumab) in HEK293-6E cells (National Research Council (NRC), Biotechnological Research Institute (BRI), Montreal, Canada). HEK293-6E cells were cultured in chemical defined F17 medium (Invitrogen, Life Technologies, Darmstadt, Germany) supplemented with $1 \mathrm{~g} / \mathrm{L}$ pluronic F68 (Applichem, Darmstadt, Germany), $4 \mathrm{mM} \mathrm{L-glutam-}$ ine (PAA) and $25 \mathrm{mg} / \mathrm{L}$ G418 (PAA) as previously described [34]. DNA was transiently transfected into $25 \mathrm{~mL}$ HEK293-6E cells in $125 \mathrm{~mL}$ Erlenmeyer shake flasks. After 48 hours of cultivation at 110 rounds per minute (rpm) in a Minitron orbital shaker (Infors, Bottmingen, Switzerland) at $37^{\circ} \mathrm{C}$ and $5 \% \mathrm{CO}_{2}$ atmosphere, one volume culture medium and a final concentration of $0.5 \%$ $(\mathrm{w} / \mathrm{v})$ of tryptone N1 (TN1, Organotechnie S.A.S., La Courneuve, France) were added. ScFv-Fc were purified via UNOsphere SUPrA column (Biorad, Munich, Germany) using a Profinia automate (Biorad, Hercules, California, USA), according to the manufacturer's instructions.

\section{Analytical SEC}

For analytical size exclusion chromatography (SEC) a Knauer PLATINblue HPLC Plus system (Knauer, Germany) with a Superdex 200 10/300 GL column (GE Healthcare, USA) was used according to the manufacturer's instructions. The column was equilibrated with the Gel Filtration HMW/LMW Calibration Kits (GE Healthcare, USA) according to the manufacturer's instructions.

\section{Tape Station}

Protein solutions were analysed with the Screen Tape P200 Protein Standard Kit (Agilent, USA) under reducing conditions on a 2200 Tape Station system (Agilent, USA) according to the manufacturer's instructions. The "P200 molecular weight standard" (Agilent) was used as a molecular marker.

\section{Additional file}

\begin{abstract}
Additional file 1: Figure S1. Screening ELISA for $85 \mathrm{~B}$ binding SCFV in HAL7/8. Culture supernatants containing soluble scFv of 92 single clones (3. panning round) were screened for their ability to bind antigen (85 B) and BSA (negative control). On positions $\mathrm{H} 9$ and $\mathrm{H} 12$ an anti-lysozyme antibody was used on lysozyme as control for scFv production and ELISA detection system. Detection of bound scFv with mouse a-c-Myc-tag 9E10 IgG followed by goat a-mouse $\lg G(\mathrm{Fc})$-HRP, development with TMB.
\end{abstract}

\section{Competing interests}

The authors have no competing financial or non-financial interests. This study was financially supported by the German Federal Ministry of Commerce, Grant No. KF 2584301. All aspects of cooperation and the generated results by the partner organisations have been mentioned in the cooperation agreement of the grant as required by the German Federal Ministry of Commerce. We did not receive any other financial or personal contribution by any other third party. Currently, there are no plans to file a patent. Following the rules of the German Federal Ministry of Commerce, LIONEX reserves its rights to develop any product based on the results or materials of this manuscript but agrees to provide the materials to research organisations only, exclusively for research use.

\section{Authors' contributions}

MF performed most of the experiments, participated in the design of the study, analysed data and drafted the manuscript. SK, SH, WP, RS, WO and RF performed some of the experiments, analysed data and provided material. $\mathrm{SD}$ participated in the design of the study and analysed data. MS and $\mathrm{MH}$ conceived the project and wrote the grant application, participated in the design of the study, analysed data and drafted the manuscript. All authors read and approved the final manuscript.

\section{Acknowledgements}

We kindly acknowledge the technical support of Susanne Daenicke and Franziska Resch. Further, we acknowledge the financial support of ZIM BMBF (contract No. KF 2584301). We also thank Elizabeth O'Brien for the careful correction of this manuscript.

\section{Author details}

${ }^{1}$ Technische Universität Braunschweig, Institut für Biochemie und Biotechnologie, Spielmannstr.7, 38106 Braunschweig, Germany. ${ }^{2}$ Lionex GmbH, Salzdahlumer Str. 196, 38126 Braunschweig, Germany. ${ }^{3}$ Helmholtz Zentrum für Infektionsforschung, Abteilung Chemische Biologie, Inhoffenstr. 7, 38124 Braunschweig, Germany. ${ }^{4}$ Leibniz-Institut für Molekulare Pharmakologie, Robert-Roessle-Str. 10, 13125 Berlin, Germany.

Received: 22 April 2014 Accepted: 1 July 2014

Published: 17 July 2014

\section{References}

1. WHO: Global Tuberculosis Report 2012. Geneva, Switzerland: 2012.

2. Dye C, Scheele S, Dolin P, Pathania V, Raviglione MC: Consensus statement. Global burden of tuberculosis: estimated incidence, prevalence, and mortality by country. WHO Global Surveillance and Monitoring Project. JAMA 1999, 282:677-686.

3. Kumar V, Robbins SL: Robbins basic pathology. 8th edition. Philadelphia, PA: Saunders/Elsevier; 2007.

4. Helb D, Jones M, Story E, Boehme C, Wallace E, Ho K, Kop J, Owens MR, Rodgers R, Banada P, Safi H, Blakemore R, Lan NTN, Jones-Lopez EC, Levi M, 
Burday M, Ayakaka I, Mugerwa RD, McMillan B, Winn-Deen E, Christel L, Dailey P, Perkins MD, Persing DH, Alland D: Rapid Detection of Mycobacterium tuberculosis and Rifampin Resistance by Use of On-Demand, Near-Patient Technology. J Clin Microbiol 2010, 48:229-237.

5. Rai DR, Kshetry NT, Bhargava D, Pokhrel BM: Comparison of Ziehl-Neelsen staining microscopy and immunochromatographic tuberculosis test for diagnosis of pulmonary tuberculosis. J Inst Med 2006, 28:15-18.

6. van Deun A, Portaels F: Limitations and requirements for quality control of sputum smear microscopy for acid-fast bacilli. Int J Tuberc Lung Dis 1998, 2:756-765.

7. Steingart KR, Ng V, Henry M, Hopewell PC, Ramsay A, Cunningham J, Urbanczik R, Perkins MD, Aziz MA, Pai M: Sputum processing methods to improve the sensitivity of smear microscopy for tuberculosis: a systematic review. Lancet Infect Dis 2006, 6:664-674.

8. Perkins MD, Cunningham J: Facing the crisis: improving the diagnosis of tuberculosis in the HIV era. J Infect Dis 2007, 196(Suppl 1):S15-S27.

9. Dheda K, Ruhwald M, Theron G, Peter J, Yam WC: Point-of-care diagnosis of tuberculosis: Past, present and future. Respirology 2013, 18:217-232.

10. WHO: An International Roadmap for Tuberculosis Research. Geneva, Switzerland: WHO; 2011.

11. Flores LL, Steingart KR, Dendukuri N, Schiller I, Minion J, Pai M, Ramsay A, Henry M, Laal S: Systematic Review and Meta-Analysis of Antigen Detection Tests for the Diagnosis of Tuberculosis. Clin Vaccine Immunol 2011, 18:1616-1627.

12. Wiker HG, Harboe M: The Antigen 85 Complex: a Major Secretion Product of Mycobacterium tuberculosis. Microbiol Rev 1992, 56:648-661.

13. Sonnenberg MG, Belisle JT: Definition of Mycobacterium tuberculosis culture filtrate proteins by two-dimensional polyacrylamide gel electrophoresis, $\mathrm{N}$-terminal amino acid sequencing, and electrospray mass spectrometry. Infect Immun 1997, 65:4515-4524.

14. Wiker HG, Sletten K, Nagai S, Harboe M: Evidence for three separate genes encoding the proteins of the mycobacterial antigen 85 complex. Infect Immun 1990, 58:272-274.

15. Kremer L, Maughan W, Wilson R, Dover L, Besra GS: The M. tuberculosis antigen 85 complex and mycolyltransferase activity. Lett Appl Microbiol 2002, 34:233-237.

16. Belisle JT, Vissa VD, Sievert T, Takayama K, Brennan PJ, Besra GS: Role of the major antigen of Mycobacterium tuberculosis in cell wall biogenesis. Science 1997, 276:1420-1422.

17. Armitige $L Y$, Jagannath $C$, Wanger $A R$, Norris SJ: Disruption of the genes encoding antigen $85 \mathrm{~A}$ and antigen $85 \mathrm{~B}$ of Mycobacterium tuberculosis H37Rv: effect on growth in culture and in macrophages. Infect Immun 2000, 68:767-778.

18. Abou-Zeid C, Ratliff T, Wiker H, Harboe M: Characterization of FibronectinBinding Antigens Released by Mycobacterium tuberculosis and Mycobacterium bovis BCG. Infect Immun 1988, 56:3046-3051.

19. Abou-Zeid C, Garbe T, Lathigra R, Wiker HG, Harboe M, Rook G, Young B: Genetic and Immunological Analysis of Mycobacterium tuberculosis Fibronectin-Binding Proteins. Infect Immun 1991, 59:2712-2718.

20. Bentley-Hibbert SI, Quan X, Newman T, Huygen K, Godfrey HP: Pathophysiology of antigen 85 in patients with active tuberculosis: antigen 85 circulates as complexes with fibronectin and immunoglobulin G. Infect Immun 1999, 67:581-588.

21. Drowart A, de Bruyn J, Huygen K, Damiani G, Godfrey HP, Stelandre M, Yernault JC, Van Vooren JP: Isoelectrophoretic characterization of protein antigens present in mycobacterial culture filtrates and recognized by monoclonal antibodies directed against the Mycobacterium bovis BCG antigen 85 complex. Scand J Immunol 1992, 36:697-702.

22. Ferrara F, Naranjo LA, Kumar S, Gaiotto T, Mukundan H, Swanson B, Bradbury AR, Andrew RM: Using phage and yeast display to select hundreds of monoclonal antibodies: application to antigen 85, a tuberculosis biomarker. PLoS One 2012, 7:e49535.

23. Mukundan H, Kumar S, Price DN, Ray SM, Lee Y, Min S, Eum S, KubicekSutherland J, Resnick JM, Grace WK, Anderson AS, Hwang SH, Cho SN, Via LE, Barry C3, Sakamuri R, Swanson BI: Rapid detection of Mycobacterium tuberculosis biomarkers in a sandwich immunoassay format using a waveguide-based optical biosensor. Tuberculosis (Edinb) 2012, 92:407-416.

24. Kashyap RS, Rajan AN, Ramteke SS, Agrawal VS, Kelkar SS, Purohit HJ, Taori GM, Daginawala HF: Diagnosis of tuberculosis in an Indian population by an indirect ELISA protocol based on detection of Antigen 85 complex: a prospective cohort study. BMC Infect Dis 2007, 7:74.
25. Kashyap RS, Dobos KM, Belisle JT, Purohit HJ, Chandak NH, Taori GM, Daginawala HF: Demonstration of components of antigen 85 complex in cerebrospinal fluid of tuberculous meningitis patients. Clin Diagn Lab Immunol 2005, 12:752-758.

26. Wallis RS, Perkins M, Phillips M, Joloba M, Demchuk B, Namale A, Johnson JL, Williams D, Wolski K, Teixeira L, Dietze R, Mugerwa RD, Eisenach K, Ellner JJ: Induction of the antigen 85 complex of Mycobacterium tuberculosis in sputum: a determinant of outcome in pulmonary tuberculosis treatment. $J$ Infect Dis 1998, 178:1115-1121.

27. Kirsch MI, Hülseweh B, Nacke C, Rülker T, Schirrmann T, Marschall HJ, Hust M, Dübel S: Development of human antibody fragments using antibody phage display for the detection and diagnosis of Venezuelan equine encephalitis virus (VEEV). BMC Biotechnol 2008, 8:66.

28. Meyer T, Stratmann-Selke J, Meens J, Schirrmann T, Gerlach GF, Frank R, Dübel S, Strutzberg-Minder K, Hust M: Isolation of scFv fragments specific to OmpD of Salmonella Typhimurium. Vet Microbiol 2011, 147:162-169.

29. Meyer T, Schirrmann T, Frenzel A, Miethe S, Stratmann-Selke J, Gerlach GF, Strutzberg-Minder K, Dübel S, Hust M: Identification of immunogenic proteins and generation of antibodies against Salmonella Typhimurium using phage display. BMC Biotechnol 2012, 12:29.

30. Schütte $M$, Thullier $P$, Pelat $T$, Wezler $X$, Rosenstock $P$, Hinz D, Kirsch MI Hasenberg M, Frank R, Schirrmann T, Gunzer M, Hust M, Dübel S: Identification of a Putative Crf Splice Variant and Generation of Recombinant Antibodies for the Specific Detection of Aspergillus fumigatus. PLoS One 2009, 4:e6625.

31. Chan C, Zhao B, Cazenave-Gassiot A, Pang S, Bendt A, Wenk M, Macary P, Hanson B: Novel phage display-derived mycolic acid-specific antibodies with potential for tuberculosis diagnosis. J Lipid Res 2013, 54:2924-2932.

32. Lillo AM, Ayriss JE, Shou Y, Graves SW, Bradbury AR: Development of phage-based single chain Fv antibody reagents for detection of Yersinia pestis. PLoS One 2011, 6:e27756.

33. Hust M, Meyer T, Voedisch B, Rülker T, Thie H, El-Ghezal A, Kirsch MI, Schütte M, Helmsing S, Meier D, Schirrmann T, Dübel S: A human scFv antibody generation pipeline for proteome research. J Biotechnol 2011, 152:159-170.

34. Jäger V, Büssow K, Wagner A, Weber S, Hust M, Frenzel A, Schirrmann T: High level transient production of recombinant antibodies and antibody fusion proteins in HEK293 cells. BMC Biotechnol 2013, 13:52.

35. Retter I, Althaus H, Münch R, Müller W: VBASE2, an integrative V gene database. Nucleic Acids Res 2004, 33:D671.

36. Anderson DH, Harth G, Horwitz MA, Eisenberg D: An interfacial mechanism and a class of inhibitors inferred from two crystal structures of the Mycobacterium tuberculosis $30 \mathrm{kda}$ major secretory protein (antigen 85B), a mycolyl transferase. J Mol Biol 2001, 307:671-681.

37. Boehm MK, Woof JM, Kerr MA, Perkins SJ: The Fab and Fc fragments of $\lg A 1$ exhibit a different arrangement from that in lgG: a study by X-ray and neutron solution scattering and homology modelling. J $\mathrm{Mol} \mathrm{BiOl}$ 1999, 286:1421-1447.

38. Artimo P, Jonnalagedda M, Arnold K, Baratin D, Csardi G, de Castro E, Duvaud S, Flegel V, Fortier A, Gasteiger E, Grosdidier A, Hernandez C, Loannidis V, Kuznetsov D, Liechti R, Moretti S, Mostaguir K, Redaschi N, Rossier G, Xenarios I, Stockinger H: ExPASy: SIB bioinformatics resource portal. Nucleic Acids Res 2012, 40:W597.

39. Bekmurzayeva A, Sypabekova M, Kanayeva D: Tuberculosis diagnosis using immunodominant, secreted antigens of Mycobacterium tuberculosis. Tuberculosis 2013, 93:381-388.

40. Lawn SD: Point-of-care detection of lipoarabinomannan (LAM) in urine for diagnosis of HIV-associated tuberculosis: a state of the art review. BMC Infect Dis 2012, 12:103.

41. Frenzel A, Fröde D, Meyer T, Schirrmann T, Hust M: Generating Recombinant Antibodies for Research, Diagnostics and Therapy Using Phage Display. Curr Biotechnol 2012, 1:33-41.

42. Knappik A, Ge L, Honegger A, Pack P, Fischer M, Wellnhofer G, Hoess A, Wolle J, Plückthun A, Virnekas B: Fully synthetic human combinatorial antibody libraries (HuCAL) based on modular consensus frameworks and CDRs randomized with trinucleotides. J Mol Biol 2000, 296:57-86.

43. Loset GA, Lobersli I, Kavlie A, Stacy JE, Borgen T, Kausmally L, Hvattum E, Simonsen B, Hovda MB, Brekke OH: Construction, evaluation and refinement of a large human antibody phage library based on the $\lg \mathrm{D}$ and IgM variable gene repertoire. J Immunol Methods 2005, 299:47-62.

44. Schofield DJ, Pope AR, Clementel V, Buckell J, Chapple SD, Clarke KF, Conquer JS, Crofts AM, Crowther SR, Dyson MR, Flack G, Griffin GJ, Hooks Y, 
Howat WJ, Kolb-Kokocinski A, Kunze S, Martin CD, Maslen GL, Mitchell JN, O'Sullivan M, Perera RL, Roake W, Shadbolt SP, Vincent KJ, Warford A, Wilson WE, Xie J, Young JL, McCafferty J: Application of phage display to high throughput antibody generation and characterization. Genome Biol 2007, 8:R254.

45. Landowski CP, Godfrey HP, Bentley-Hibbert SI, Liu X, Huang Z, Sepulveda R, Huygen K, Gennaro ML, Moy FH, Lesley SA, Haak-Frendscho M: Combinatorial Use of Antibodies to Secreted Mycobacterial Proteins in a Host Immune System-Independent Test for Tuberculosis. J Clin Microbiol 2001, 39:2418-2424

46. Kremer L, Baulard A, Estaquier J, Poulain-Godefroy O, Locht C: Green fluorescent protein as a new expression marker in mycobacteria. Mol Microbiol 1995, 17:913-922.

47. Huygen K, Lozes E, Gilles B, Drowart A, Palfliet K, Jurion F, Roland I, Art M, Dufaux M, Nyabenda J: Mapping of TH1 helper T-cell epitopes on major secreted mycobacterial antigen $85 \mathrm{~A}$ in mice infected with live Mycobacterium bovis BCG. Infect Immun 1994, 62:363-370.

48. Launois P, DeLeys R, Niang MN, Drowart A, Andrien M, Dierckx P, Cartel JL, Sarthou JL, Van Vooren JP, Huygen K: T-cell-epitope mapping of the major secreted mycobacterial antigen Ag85A in tuberculosis and leprosy. Infect Immun 1994, 62:3679-3687.

49. Roche PW, Peake PW, Billman-Jacobe H, Doran T, Britton WJ: T-cell determinants and antibody binding sites on the major mycobacterial secretory protein MPB59 of Mycobacterium bovis. Infect Immun 1994, 62:5319-5326.

50. Commandeur S, Lin MY, van Meijgaarden KE, Friggen AH, Franken KL, Drijfhout JW, Korsvold GE, Oftung F, Geluk A, Ottenhoff TH: Double- and monofunctional CD4(+) and CD8(+) T-cell responses to Mycobacterium tuberculosis DosR antigens and peptides in long-term latently infected individuals. Eur J Immunol 2011, 41:2925-2936.

51. Shen G, Behera D, Bhalla M, Nadas A, Laal S: Peptide-based antibody detection for tuberculosis diagnosis. Clin Vaccine Immunol 2009, 16:49-54.

52. Altschul SF, Gish W, Miller W, Myers EW, Lipman DJ: Basic local alignment search tool. J Mol Biol 1990, 215:403-410.

53. Lightbody KA, Girvin RM, Pollock DA, Mackie DP, Neill SD, Pollock JM: Recognition of a common mycobacterial T-cell epitope in MPB59 of Mycobacterium bovis. Immunology 1998, 93:314-322.

54. Valle MT, Megiovanni AM, Merlo A, Li Pira G, Bottone L, Angelini G, Bracci L, Lozzi L, Huygen K, Manca F: Epitope focus, clonal composition and Th1 phenotype of the human CD4 response to the secretory mycobacterial antigen Ag85. Clin Exp Immunol 2001, 123:226-232.

55. D'Souza S, Rosseels V, Romano M, Tanghe A, Denis O, Jurion F, Castiglione N, Vanonckelen A, Palfliet K, Huygen K: Mapping of murine Th1 helper T-Cell epitopes of mycolyl transferases Ag85A, Ag85B, and Ag85C from Mycobacterium tuberculosis. Infect Immun 2003, 71:483-493.

56. Murphy $K$, Travers $P$, Walport M, Janeway C: Janeway's immunobiology. 7th edition. New York: Garland Science; 2008.

57. Arnon R: Enzyme inhibition by antibodies. Acta Endocrinol Suppl (Copenh) 1975, 194:133-153.

58. Mustafa AS, Abal AT, Shaban F, El-Shamy AM, Amoudy HA: HLA-DR binding prediction and experimental evaluation of T-cell epitopes of mycolyl transferase 85B (Ag85B), a major secreted antigen of Mycobacterium tuberculosis. Med Princ Pract 2005, 14:140-146.

59. Gaseitsiwe S, Valentini D, Mahdavifar S, Magalhaes I, Hoft DF, Zerweck J, Schutkowski M, Andersson J, Reilly M, Maeurer MJ: Pattern recognition in pulmonary tuberculosis defined by high content peptide microarray chip analysis representing 61 proteins from M. tuberculosis. PLoS One 2008, 3:e3840

60. Nguyen YH, Ma X, Qin L: Rapid identification and drug susceptibility screening of ESAT- 6 secreting Mycobacteria by a NanoELIwell assay. Sci Rep 2012, 2:635.

61. Powers DB, Amersdorfer P, Poul M, Nielsen UB, Shalaby MR, Adams GP Weiner LM, Marks JD: Expression of single-chain Fv-Fc fusions in Pichia pastoris. J Immunol Methods 2001, 251:123-135.

62. Yin $X$, Zheng L, Lin L, Hu Y, Zheng F, Hu Y, Wang Q: Commercial MPT64-based tests for rapid identification of Mycobacterium tuberculosis complex: A meta-analysis. J Infect 2013, 67:369-377.

63. Ngamlert K, Sinthuwattanawibool C, McCarthy KD, Sohn H, Starks A, Kanjanamongkolsiri P, Anek-vorapong R, Tasaneeyapan T, Monkongdee P, Diem L, Varma JK: Diagnostic performance and costs of Capilia TB for
Mycobacterium tuberculosis complex identification from broth-based culture in Bangkok, Thailand. Trop Med Int Health 2009, 14:748-753.

64. Geisbrecht BV, Nikonenko B, Samala R, Nakamura R, Nacy CA, Sacksteder KA: Design and optimization of a recombinant system for large-scale production of the MPT64 antigen from Mycobacterium tuberculosis. Protein Expr Purif 2006, 46:64-72.

65. Chu TJ, Yuann JP: Expression, purification, and characterization of protective MPT64 antigen protein and identification of its multimers isolated from nontoxic Mycobacterium tuberculosis H37Ra. Biotechnol Appl Biochem 2011, 58:185-189.

66. Oettinger T, Holm A, Haslov K: Characterization of the delayed type hypersensitivity-inducing epitope of MPT64 from Mycobacterium tuberculosis. Scand J Immunol 1997, 45:499-503.

67. Sambrook J, Russell D: Molecular Cloning: A Laboratory Manual. 3rd edition. New York: Cold Spring Harbor Laboratory Press; 2001

68. Schirrmann T, Hust M: Construction of human antibody gene libraries and selection of antibodies by phage display. Methods Mol Biol 2010, 651:177-209.

69. Hust M, Steinwand M, Al-Halabi L, Helmsing S, Schirrmann T, Dübel S: Improved microtitre plate production of single chain Fv fragments in Escherichia coli. N Biotechnol 2009, 25:424-428.

70. Frank R: Spot-synthesis: an easy technique for the positionally addressable, parallel chemical synthesis on a membrane support. Tetrahedron 1992, 48:9217-9232.

71. Frank R: The SPOT-synthesis technique. Synthetic peptide arrays on membrane supports-principles and applications. J Immunol Methods 2002, 267:13-26.

72. Frank R, Dübel $\mathrm{S}$ : Analysis of protein interactions with immobilized peptide arrays synthesized on membrane supports. In Protein-Protein Interactions, A Molecular Cloning Manual. 2nd edition. Edited by Golemis E, Adams PD. Cold Spring Harbor, N.Y: Cold Spring Harbor Laboratory Press; 2005.

73. Laemmli UK: Cleavage of structural proteins during the assembly of the head of bacteriophage T4. Nature 1970, 227:680-685.

74. Schägger H, von Jagow G: Tricine-sodium dodecyl sulfate-polyacrylamide gel electrophoresis for the separation of proteins in the range from 1 to 100 kDa. Anal Biochem 1987, 166:368-379.

75. Ronning DR, Vissa V, Besra GS, Belisle J, Sacchettini JC: Mycobacterium tuberculosis Antigen 85A and 85C Structures Confirm Binding Orientation and Conserved Substrate Specificity. J Biol Chem 2004, 279:36771-36777.

doi:10.1186/1472-6750-14-68

Cite this article as: Fuchs et al:: Novel human recombinant antibodies against Mycobacterium tuberculosis antigen 85B. BMC Biotechnology 2014 14:68

\section{Submit your next manuscript to BioMed Central and take full advantage of:}

- Convenient online submission

- Thorough peer review

- No space constraints or color figure charges

- Immediate publication on acceptance

- Inclusion in PubMed, CAS, Scopus and Google Scholar

- Research which is freely available for redistribution 